\title{
NAMING AND PRAISING IN HUMANITARIAN NORM DEVELOPMENT
}

\author{
By MARGARITA H. PETROVA
}

Published IN WORLD POLITICS 71, no. 3 (2019), 586-630

\begin{abstract}
To examine the early development of humanitarian norm cascades, the author focuses on processes that led to the adoption of the 1997 Mine Ban Treaty and the 2008 Convention on Cluster Munitions. Even though major military powers such as the United States, Russia, and China opposed these initiatives, the processes set in motion quick norm cascades that brought about international legal norms stigmatizing land mines and cluster munitions. It is conventionally asserted that international norms emerge either due to great power backing or despite great power opposition, but the author argues that new norms can take off because of great power opposition. When NGOs and leading states actively foster normative change, a particular type of norm cascade is engineered-one generated by different mechanisms and starting earlier than postulated in the literature. Early norm cascading is driven not by emulation of peers and NGO naming and shaming of laggard states, but rather by leadership aspirations and naming and praising.
\end{abstract}

HE war against terrorism that launched in the wake of the attacks on September
11,2001 , and continues in some form to the present day is often described as a nadir for international law, particularly international humanitarian law (IHL), which regulates the conduct of armed conflict. But in this period, IHL has strengthened in one important aspect: the protection of civilians against weapons causing indiscriminate and disproportionate harm. In 2008, after fifteen months of negotiation, the Convention on Cluster Munitions (CCM) was agreed upon, comprehensively banning the use, production, World Politics 1-Xx doi: $10.1017 /$ S0043887 tk. 
and sale of cluster munitions, and in slightly over a year it entered into force. Even more impressive, the 1997 Mine Ban Treaty (MBT), which comprehensively prohibits antipersonnel land mines, was negotiated in a year and had "the fastest entry-into-force of any major multilateral treaty ever." ${ }^{1}$ The speed of these normative developments is all the more notable because major military powers opposed both treaties.

What accounts for the rapid transformation of two common and militarily useful weapons into stigmatized instruments of war ${ }^{2}$ This article seeks to refine the theoretical concept of norm cascades in international relations and to contribute to the empirical study of nonhegemonic norm development. I argue that in cases characterized by active NGO mobilization and state leadership, a norm cascade could start when about 15 percent of all states support an emerging norm. This number is lower than the postulated tipping point of one-third of all states, ${ }^{3}$ and thus occurs earlier in the process. State leaders can strategically engineer a cascade through concerted diplomatic efforts coupled with NGO campaigning aimed at broadening state support. Instead of peer pressure and emulation, ${ }^{4}$ in such cases norm development is fed by the early supporters’ desire to play vanguard roles as norm champions in the face of great power opposition.

In particular, I focus on the process of altercasting, whereby NGOs and other norm promoters project onto states (especially those that are small, middle-sized, or developing) the roles of leaders and good international citizens. Rather than just pressuring states through naming and shaming, NGOs encourage early norm support through naming and praising. At the same time, NGOs often cast dominant powers, especially the United States superpower, in the role of rogues or bullies that obstruct new international norms and pressure weaker actors not to support them. In a reversal of conventional international relations wisdom, international norms emerge not because of 
dominant state backing and not even despite great power opposition. ${ }^{5}$ New norms can also take off because of great power opposition and the ways in which NGOs frame the negotiation process and the roles that states could play in it. Whereas scholars have highlighted the role of Western middle powers in nonhegemonic norm development, ${ }^{6} \mathrm{I}$ focus on the role of developing states, especially those in Africa. Usually portrayed as norm laggards, these states are norm champions in the cases I examine, and norm development depends on their support.

The article proceeds as follows: I examine the norm cascade and tipping point concepts, situate my argument within the relevant IR literature, and evaluate alternative explanations. I then focus on the role of altercasting and status seeking in generating early norm support. To address criticisms that any norms developed without the major powers are insignificant, I show their effects on US, Israeli, and Russian practices regarding cluster munitions. The conclusion looks at the implications of nonhegemonic norm development for international order.

\section{NORM EMERGENCE AND CASCADE}

A norm is defined as "collective expectations for the appropriate behavior for actors with a given identity.”7 Martha Finnemore and Kathryn Sikkink conceptualize the norm life cycle in three phases: emergence, cascade, and internalization. ${ }^{8}$ The latter two phases of norm diffusion from the international into the domestic sphere (norm socialization), have been widely examined. ${ }^{9}$ The prominent boomerang and spiral models outline the processes by which norm entrepreneurs influence state behavior regarding human rights protection. ${ }^{10}$ The models show how laggard states are socialized into international norms when domestic structures are closed to demands for change from domestic actors but 
could be opened through concerted pressure by NGOs, international organizations, and foreign governments.

Both boomerang and spiral models are premised on the norms' nature- that is, established international norms denoting the identity of states in good international standing. ${ }^{11}$ Thus the models belong to the norm cascade phase, characterized by "rapid, dramatic shifts in the legitimacy of norms” ${ }^{12}$ following a tipping point of support by a critical mass of states. The mass is measured by the number of states endorsing a norm (set at around one-third of all states, based on empirical cases), ${ }^{13}$ while "critical” denotes the quality of norm-supporting states reflected in their moral stature or their importance for achieving the substantive norm objectives.

Hence, the mass is large enough and comprises critical states so as to "redefine the appropriate behavior for the identity called 'state' or some relevant subset of states.”14 When the tipping point is reached, the effects of peer pressure and emulation kick in and make normative progress very probable, if not irreversible. In the case of the 1997 MBT, for example, some key states joined because "their leaders felt it intolerable to be left outside the club of responsible international citizens once they judged that the balance had tipped such that resistance signaled outlier status.”15

But the other element of the tipping concept—speed-receives less attention. Tipping happens “where growth accelerates dramatically and sustains itself”; ${ }^{16}$ it marks a watershed between the mechanisms characterizing the phases of norm emergence and cascade. Before the tipping, norm entrepreneurs - motivated by altruism and ideational commitment-use persuasion to move the process forward. After the tipping, norm support is driven mainly by peer pressure or imitation, with less need for domestic pressure or norm-entrepreneur efforts. ${ }^{17}$ 
Argument: RApid Norm DeVelopment, Altercasting, AND LEAdership

Although norm entrepreneurship still plays a role after the tipping point, ${ }^{18}$ the cascade metaphor (mixed with others) denotes a contagion or bandwagon effect. ${ }^{19}$ This notion can be traced to Thomas Schelling's tipping games, in which what actors do depends on the behavior of others. Thus, passing the tipping point produces a self-sustaining dynamic, much like the way a critical mass of fissile material triggers a nuclear chain reaction under particular conditions. ${ }^{20}$ But the crucial element is the conditions leading to the event-in the case of my argument, a norm cascade. ${ }^{21}$ This article contributes to an understanding of norm development in international affairs by investigating the mechanisms that underlie early norm support and the timing of the tip.

To reiterate, existing work claims that the tipping point occurs when about onethird of all states support a norm and because "standard ways of showing the operation of a norms cascade do not yet exist," two proxy measures have been suggested: "collections of norm-affirming events," such as "verbal or written statements asserting the norm,"22 and in the case of norms embodied in treaties where entry into force indicates the tipping point, ratifications. ${ }^{23}$ Depending on the norm trajectory, these proxies can measure different processes. When a number of states formulate and support a norm without legal codification, the growth of norm-affirming events represents a norm cascade. When a norm is accepted by states first and then embedded in a treaty, norm-affirming events capture an early cascade of support. Ratifications indicate a mature cascade of the institutionalized norm as roughly the same states endorse the norm twice- -by first signing and then ratifying a treaty, or by first adopting a norm domestically and then ratifying an international treaty. 
I argue that the timing of the tipping point depends on political dynamics. Under some conditions, a norm cascade could start earlier than postulated in the literature. When a small number of states support an emerging norm and work actively in tandem with NGOs and international organizations, they can trigger and sustain a cascade. I show that a cascade can start with as little as 15 percent of all states supporting a norm, although the number is of limited relevance on its own. What matters are the processes through which a cascade is purposefully engineered. A tipping threshold of 15 percent also means that the norm emergence phase is quite condensed, and the cascade happens early and moves rapidly. I focus on early support for norm making (before codification in a treaty). ${ }^{24}$ This phase can be defined as norm emergence, since the norm hasn't been fully concretized in a treaty. Nevertheless, its contours are already clear and the dynamics of mobilizing early norm support exhibit the hallmarks of a cascade-a sudden and swift increase in state support after the 15 percent threshold. Thus, I conceptualize the process as a cascade of support for a fledgling norm. ${ }^{25}$

According to the norm life-cycle model, domestic pressure is paramount during norm emergence and support is motivated by “empathy, altruism, and ideational commitment” and results from persuasion. ${ }^{26}$ At the cascade phase, norms tip when “pressures of emulation and identity” at the international level outweigh interest-based considerations. $^{27}$

But a different process can also take place. Cascades can be generated by the mobilization of pride rather than the mobilization of shame, and by leadership, not just imitation. States hasten to lead a normative development or to join early because the prize of leadership goes to early norm creators and adopters. That motivation is distinct from both sincere normative commitment and shame avoidance, the mechanisms identified at 
the emergence and cascade phases, respectively. ${ }^{28}$ Status seeking and leadership seeking advance the tipping point and drive the initial stages of the cascade. Farther along the curve, shame avoidance begins to bring in states from the sidelines. But I argue that peer pressure and emulation don’t have strong effects until about 50 percent of all states change positions, triggering concerns about remaining an outlier. Even then, states indifferent to or adversely affected by the norm are more likely to accept it gradually to avoid being left behind than to rush in cascade-like. Domestic and international processes are also tightly entwined in the cases examined here. In a few leading Western states domestic pressure is used to jumpstart international norm development, ${ }^{29}$ while in developing states the international and regional levels occupy center stage.

Norm support doesn’t grow automatically. Leading states and NGOs strategically engineer norm development and ensure that supporters follow. By praising norm leadership and elevating its visibility, they increase its value as a source of state status. Shaming tactics are reserved for those states that remain reluctant to engage fully but have already established reputations as good international citizens. By shaming, NGOs constrain the opponents' ability to interfere with the norm-making process and to impose costs on its leaders. In contrast to the boomerang and spiral models of norm diffusion, pressure isn't exerted by the strong on states that are deviant or weak. Instead, small states and NGOs pressure big powers to endorse a new norm and in the process cast smaller states as leaders.

\section{Altercasting as a CAscading Mechanism}

The altercasting concept is a refinement of symbolic interactionism, ${ }^{30}$ specifically of Erving Goffman's work on self-representation. ${ }^{31}$ Altercasting looks at how actors define 
the roles others should play in a social situation. It involves "projecting an identity, to be assumed by other(s) ... which is congruent with one’s own goals.” ${ }^{32}$ An actor doesn’t simply control impressions of himself, he "takes a direct hand at changing the array of behavioral alternatives available to alter."33 Altercasting places actors into roles that create particular social relations between altercaster and target, structures the social environment of targets, and channels the latter's behavior in a desired direction.

Altercasting can be negative or positive. In negative altercasting, ${ }^{34}$ altercasters project a negative identity for the target and use shame to induce distancing from the negative role and achieve the aimed behavioral change. Although it is similar to naming and shaming (when a state is cast as being duplicitous for not living up to its own professed values), negative altercasting involves casting a state in the role of a rogue outside the international community if it opposes a new norm, that is, in the absence of a concrete prior commitment to an established norm. To avoid the outcast's role, the state must comply with the altercaster’s demands. In contrast, positive altercasting projects desirable roles that states assume to be perceived as good. ${ }^{35} \mathrm{I}$ argue that positive altercasting involves mobilization of pride or naming and praising. Altercasters use praise to encourage states to take the lead in norm creation. States are motivated not by a desire for conformity, but by a willingness to stand apart as members of the vanguard-being better than the rest, sometimes better than the best. Both types of altercasting are forms of social influence and depend on the actors’ need for self-esteem and social standing. ${ }^{36}$ But their motivational mechanisms are different—status maintenance and avoiding stigma versus status enhancement and striving for leadership. The use of praise to motivate states is sometimes mentioned in the literature, ${ }^{37}$ but generally, it has received scant attention. I 
address this oversight by looking at how NGOs cast states into positive, norm-promoting roles.

The effect of altercasting depends on the identities of the targets and altercasters, their relationship, and the message itself. ${ }^{38}$ Although most states aspire to be perceived as good international citizens, some respond to altercasting more than others do. Amy Gurowitz argues that states uncertain about their place in international society are more likely to yield to pressure to adopt international norms. ${ }^{39}$ Secondary-status states can be expected to aspire to improve their standing. Altercasting matters in these cases, since the status or social ranking of states depends on the perceptions of others in international society. ${ }^{40}$ For states that can’t claim status based on their material capabilities, ideational resources, such as active diplomacy and belonging to a group of states working to create progressive international norms, can provide it. ${ }^{41}$ States seeking regional primacy can also be expected to develop both material and ideational bases of status ${ }^{42}$ as they vie for status among dominant states. Hence, status deficit and status seeking both facilitate altercasting. Altercasting differs from cases where naming and shaming is expected to work, since the latter requires that actors have already rhetorically accepted certain norms and can harm their reputation by not complying with them. ${ }^{43}$

The identity of the altercasters is another factor. According to much of the literature, great powers grant status to small and middle powers when the latter perform useful system- and hegemony-sustaining roles. ${ }^{44}$ In contrast, I argue that NGOs and smaller states can also confer status, including by altercasting states as leaders on the international stage. When big powers praise or castigate states, it can be seen as patronizing and counterproductive. The same message can resonate better when delivered by actors that are weaker but legitimate-say, experts or moral authorities on an issue. 
And whereas smaller states can gain status through norm advocacy, which broadly speaking supports the international order, it doesn't necessarily support the hegemon. It can involve confrontation with and negative altercasting of the dominant powers, as I argue below.

In particular, the social relationship between altercaster and target matters. ${ }^{45}$ Major NGOs that played key roles in the cases I examine here, such as Human Rights Watch (HRW), enjoy name recognition, are knowledgeable about the substantive issues, and are savvy about negotiation dynamics (tracking state positions and devising strategies to respond to them)—-the last a skill the negotiating delegations of many small states lack. This expertise places NGOs in positions of influence and authority, which can also spur resentment. ${ }^{46}$ Butby asking states to be leaders and to help establish new standards, NGOs cast the states in an agential, independent role that resembles self-motivation more than external influence. ${ }^{47}$ NGOS may be authoritative actors, but they depend on the support of developing states, which are thus endowed with autonomy and responsibility. As a result, altercaster and target are placed in mutually dependent roles, which increases altercasting's chance of success. ${ }^{48}$

The cost of leadership also affects the success of altercasting. The cheaper it is to play a positive role, the easier it is for actors to assume that role (although the low cost per se doesn’t lead to cascading norm support). But emotional processes involving injured pride, righting an injustice, or defying coercers can still motivate action in the face of higher costs. ${ }^{49}$ In this respect, negative altercasting of dominant states becomes important.

Some social experiments find that positive altercasting can be more effective than negative. ${ }^{50}$ It is also argued that people with whom one has a positive and close 
relationship are likely to be effective persuaders. ${ }^{51}$ I argue that positive altercasting employed at the early norm-setting stage also works when coupled with the negative altercasting of others because status ranking involves group comparisons and differentiation from others. When states that are often the targets of international tutelage and criticism are cast in prominent independent roles internationally, highlighting these roles in contrast to the "backward" positions of otherwise dominant states overturns the traditional pecking order. ${ }^{52}$ It is a chance for small states to enhance their standing internationally while bringing dominant powers down a peg or two. Provided dominant states wish to reject the bully role, negative altercasting also constrains them from using heavy-handed pressure, thus limiting the backlash that norm leaders could otherwise expect. Although similar mechanisms are at play regarding Western states, ${ }^{53}$ I focus on the altercasting of developing states, especially those in Africa because this aspect challenges the way they're typically seen—as laggards on human rights and humanitarian norms. ${ }^{54}$

From the NGOs’ perspective, focusing on and criticizing major states makes sense for two reasons. It automatically increases issue salience because big players make frontpage news. By speaking truth to power, organizations also enhance their reputations for independence and credibility. This aspect in turn influences how other actors view them, especially developing states similarly aspiring to independence. NGOs that are perceived as independent are more likely to be accepted as legitimate actors and to be effective altercasters. ${ }^{55}$ And though I focus primarily on NGOs, established reputations of impartiality and honest brokerage also help small and middle powers, such as Norway and Canada, to be accepted as leaders. 
What actors say and do matters, but state behavior matters in conjunction with the frames within which it is embedded. When a state rhetorically endorses certain values but fails to live up to them, that state becomes a rhetorically entrapped target of naming and shaming for its hypocrisy. ${ }^{56}$ Hence, a state that has proclaimed early support for addressing the humanitarian problems of certain weapons, but fails to act on it, is an easier target for criticism than states that consistently oppose any regulations and don't share liberal values. The US, as a unipole (sole superpower), has been particularly vulnerable to critiques of hypocrisy. It has built and promotes the international liberal order and thus is expected to back values associated with it. But due to its global reach and responsibilities, the US frequently faces conflicts between the pursuit of different values, such as security and human rights. As a result, it often engages in inconsistent policies and covers them up with hypocritical rhetoric. That hypocrisy sustains international order, but it also poses particular legitimacy challenges for the unipole leader. ${ }^{57}$ In addition, any major power that's seen as putting inappropriate pressure on others is bound to be resented. Countries that are opposed to an emerging norm but are not actively trying to influence others attract less criticism.

Thus, I establish some scope conditions for quick norm development. I argue that theoretically, the mechanisms driving an early cascade can vary-leadership ambitions, concern for international status, and naming and praising, instead of peer pressure and naming and shaming. And empirically, under conditions of NGO and state leadership, the tipping point at which a cascade starts can be earlier than currently accepted in the literature.

I argue that positive altercasting underlies the cascading of support for a fledgling norm during the treaty-making process. The mechanism remains at work after a treaty is 
adopted and states ratify it, ${ }^{58}$ but the scope for shaming increases as the new, legal, norm is established. In both treaty making and ratification, praising and shaming coexist during the later cascade phases (after roughly 50 percent of all states support it). Positive altercasting opens up opportunities for shaming norm leaders that don't live up to their commitments, and the opportunity for peer pressure increases as the group of normsupporting peers grows bigger.

\section{ALternative EXPLANATIONS AND METHOD}

Fast norm cascades could be explained by hegemonic leadership, which states follow due to pressure or emulation. And cascades should occur faster for lowest-commondenominator norms that don’t require costly commitments. It's also easier to adopt norms when they don't break radically new ground but rather build upon a dense network of established norms, or when there are more opportunities to negotiate them compared to earlier periods. Norm resonance and grafting make a difference for the establishment of norms, including those examined here. ${ }^{59}$ Normative cascades usually build upon existing norms and extend their logic to new problem areas. ${ }^{60}$ The latter aspects are captured by the “world time” idea — for example, faster normative change after the Cold War can be explained by the growth in international organizations, human rights norms, global interconnectedness, and ideological homogeneity. ${ }^{61}$

To assess these factors, I compare the 2008 Convention on Cluster Munitions with the $\mathrm{CCW}^{62}$ Protocol V on Explosive Remnants of War, adopted in 2003, and the 1997 Mine Ban Treaty with the cCw Amended Protocol II on land mines, adopted in 1996. Protocol V and Amended Protocol II address the same substantive issues and constitute most similar cases to the CCM and MBT respectively, but differ with regard to their speed of ratification, 
their extent, and the composition of state support. ${ }^{63}$ In figures 1 and 2, I illustrate the differences between the two pairs of treaties by comparing their ratification rates, which measure support for the institutionalized norms and serve as proxy for early norm cascading.

I find the alternative explanations unconvincing. The MBT and CCM ratifications were faster than those of the respective Ccw protocols, although the pairs of treaties pertain to the same time periods and normative pool. ${ }^{64}$ If grafting and world time were key factors, they should have affected the treaties similarly. The fact that the CCW protocols, backed by major powers, impose obligations that are easier to fulfill compared to those of CCM and MBT but generated less and slower state support, casts doubt on established realist accounts.

It may be that the difference in ratification speed is linked to the particular CCW framework. To become a party to the CCW, a state must ratify at least two of its protocols, which can be a somewhat burdensome process. But for a country already interested in signing one protocol, the ratification of another can be fairly unproblematic. For example, CCW Protocol I consists of one sentence: "It is prohibited to use any weapon the primary effect of which is to injure by fragments which in the human body escape detection by Xrays." It aimed to prohibit a weapon that states suspected the US had used in Vietnam, which turned out not to exist. ${ }^{65}$ The emphasis on primary effect makes the protocol almost meaningless—and thus hardly an obstacle for states willing to ratify another protocol.

Numerous other factors, including strength of rules, costs and benefits of commitment, and domestic legislative systems, can affect norm adoption speed and subsequent treaty ratification. Scholars have used statistical methods to explore the factors influencing the ratification of single treaties ${ }^{66}$ or the human rights regime as a whole, but these can obscure contextual nuances. ${ }^{67}$ 
I develop in-depth case studies of the MBT and CCM negotiation dynamics representing support for the fledgling norms, based on examination of diplomatic documents, NGO reports, eighteen interviews with NGO members and government officials from states with different roles in the negotiation processes, ${ }^{68}$ and nonparticipant observation in four negotiations conferences on cluster munitions. The interviews on the cluster munitions case were conducted before, during, and after the treaty negotiations, which helps detect distorted or misremembered information. I triangulate interview data with other sources (diplomatic records, media coverage, NGO reports, and personal observations) to enhance the validity of my findings.

\section{Background on the Land Mine And Cluster Munition Cases}

In the late 1980s and early 1990s, NGOs working in postconflict areas ran into the land mine problem. In places like Angola, Cambodia, and Mozambique, land mines were killing and maiming civilians and impeding postconflict reconstruction. Whatever utility the mines may have had during a war was far outweighed by their toll on innocent civilians long after the conflict's end. ${ }^{69}$

“Cluster munition” (CM) designates a ground-launched or airdropped rocket/dispenser that "scatter[s] widely smaller submunitions, which usually number in the dozens or hundreds." ${ }^{70}$ CMs pose dangers to civilians during attacks due to their inaccuracy, large number, and wide dispersal. In addition, a significant percentage of submunitions fail to detonate upon impact, leaving numerous duds that function as de facto land mines. Despite these problems, it was argued that CMs had significant military utility. The launch of numerous submunitions in one strike was cost efficient and their wide coverage made them effective against moving targets. But serious humanitarian 
problems became apparent with CM use, starting in Kosovo in 1999 and followed by Afghanistan, Iraq, and Lebanon in 2006.

In 1992, Human Rights Watch, Handicap International, Medico, Mines Advisory Group, Vietnam Veterans of America Foundation, and Physicians for Human Rights launched the International Campaign to Ban Landmines (ICBL). The group advocated the opening of negotiations on land mines in the CCW, and convinced France to call for a Review Conference in 1995. Similarly, in 2000, after NATO’s use of CMs in Kosovo, NGOs and the International Committee of the Red Cross argued for addressing the problem of unexploded CMs, and the issue was included in the CCW agenda.

But due to the CcW's consensus-based decision-making process and the veto of major military powers, it failed to provide prompt solutions to these humanitarian concerns. The 1996 Amended Protocol II imposed restrictions only on the use and design of mines. Its weakness motivated Canada to launch the Ottawa Process to negotiate a ban outside of established diplomatic fora. Similarly, talks on CMs and explosive remnants of war resulted in the 2003 CCW Protocol V. This protocol tried to address the postconflict problems of unexploded ordnance, but didn’t cover CM use- one of its main causes. HRW, Handicap International, Landmine Action, Mines Action Canada, and Pax Christi, among other NGOs, formed the Cluster Munition Coalition (CMC) to continue work on CMs. Over the following three years, the CCW dragged on, discussing compliance of CM use with international humanitarian law principles. Even after the 2006 Lebanon War, when extensive CM use made the problem even more urgent, states in the CCW still couldn't agree to start negotiations. This failure opened the way for Norway to initiate the so-called Oslo Process and fast-track negotiations on CMs outside the CCW. ${ }^{71}$ 


\section{MEASURING THE EARLY TIPPING OF SUPPORT FOR WEAPON BANS}

I use norm-affirming events, ${ }^{72}$ such as state statements in favor of a land mine ban and international negotiations on CMs, to estimate the emergence and early cascading of the norms against land mines and CMs. The concrete indicators are adopting domestic measures or statements favoring weapons bans, attending as full participants the first meetings of the two processes, endorsing specific declarations committing states to negotiate bans at particular stages in the processes, fully participating in the final negotiations, and signing the treaties. ${ }^{73}$ Such measures capture state support for international action to end the humanitarian impact of these weapons, as well as their growing stigmatization as unacceptable weapons.

In the examined cases, an early tipping point emerges when some thirty states (about 15 percent of all) show support for international bans. This point coincides with when the initiators of the processes took the lead in establishing international legal prohibitions. State support grew most quickly in the months following the announcement of alternative negotiations. Support had cascaded by the time of the final negotiating conferences and the official signing ceremonies, and slowed down thereafter. Figures 3 and 4 illustrate this dynamic.

Regarding the impact of critical states, material power or substantive engagement in the field (that is, weapons use) weren't crucial—-the cascades unfolded despite the opposition or absence of major military powers like the US, Russia, or China.

The role of the next big powers in line, France and the UK, is more complicated. Though both participated in the first meeting of the land mine process in October 1996, they were reluctant followers afterward, preferring action in the Conference on Disarmament. They came fully onboard only at the penultimate conference in June 1997. ${ }^{74}$ 
Similarly, these two states participated throughout the CM process but remained ambivalent in their support until the last negotiation conference, in May 2008. The UK U-turn to back a comprehensive prohibition at this conference has been portrayed as decisive for keeping its NATO allies in the process. ${ }^{75}$ Although this may be true of Canada (and Australia) on one provision about joint operations with nonparty states, the other participating countries already had stronger positions than the UK's. French and British participation added weight to the processes and, in the CM case, probably helped to keep reluctant NATO states onboard. ${ }^{76}$ At the same time, major power resistance to the negotiations helped to mobilize support by smaller states, especially affected ones, which was critical for the cascading of norms addressing weapon effects. ${ }^{77}$

In addition to the usual Western small and middle powers active on humanitarian issues, the majority of states supporting strong bans came from Africa, Latin America, and the Pacific Islands. These states represented 56 and 62 percent of those signing the CCM and MBT, respectively, in the first month they were open for signature.

\section{GENERATING MOMENTUM In INTERNATIONAL NORM MAKING:}

\section{Status SeEking AND Positive And Negative Altercasting}

In this section, I focus on how support for the fledgling norms was mobilized among developing, especially African, states. From a purely military and economic perspective, such support doesn't make sense. Indeed, it can be argued that land mines are low-cost equalizers of military capabilities between technologically advanced states and weak states. ${ }^{78}$ Whereas rich countries could easily switch to advanced weapons, poor states would be denied cheap weapons of defense. Similarly, although CMs are more advanced and expensive than land mines, they're more affordable than precision-guided munitions. 
Can states gain other material benefits from supporting the bans? In the land mine case, some African states had serious contamination problems, and some ban proponents suggested that funding for demining could be linked to state commitments toward a ban. ${ }^{79}$ There might have been expectations that norm support would result in increased aid for demining and development. ${ }^{80}$ Thus, it seemed likely that contaminated countries would be the earliest supporters. In 1999, six African countries were among the most contaminated (Angola, Eritrea, Ethiopia, Mozambique, Somalia, and Sudan), and two of those (Angola and Mozambique) were among the biggest recipients of mine-action funds. ${ }^{81}$ Of the six, only Mozambique was among the sub-Saharan African countries that ratified the MBT in its first two years, and there's no systematic evidence that minecontamination affects the likelihood of ratification. ${ }^{82}$ In addition, the strongest ban supporter, South Africa, was a major land mine producer. On CMs, Zambia-a country with a very small contamination problem that was discovered only during the negotiations (most African countries weren’t contaminated by CMs)_-took the lead. Indeed, given MBT’s demining requirement, African states should have been wary of another process that could divert donor attention. And South Africa, a producer of the self-destructing CMs banned by the treaty, ${ }^{83}$ should have shunned the process instead of going along with it, signing and eventually ratifying the treaty.

I argue that NGOs, core pro-ban states, and international agencies strategically mobilized African states to play an active part in both processes by altercasting them as leaders in contrast to the retrograde role of dominant and domineering powers, especially the US and the UK, on CMs. 
A key element in generating momentum behind the negotiating processes was the organization of a series of regional meetings to attract new states, clarify issues, and solidify state support. The regional focus aimed to engage local actors and catalyze support from the ground up. The ban processes could thus be presented as an autonomous undertaking, and not something imposed upon states.

The core group of pro-ban countries hosted all the negotiation conferences on CMs. ${ }^{84}$ To get more countries to participate, the core group financed a sponsorship program through the UN Development Program to cover expenses for delegates from developing countries. This program, along with direct contributions from core states, also financed the organization of most regional meetings. The goal was to level the playing field and allow developing states to have their voices heard in the negotiations.

Engineering momentum thus took more than humanitarian appeals. It was also due to states being able to allot the necessary resources to get the process going and to plan it in a way that allowed radical supporters to participate while limiting the leverage of states that opposed a comprehensive CM prohibition. ${ }^{85}$ Thus, the largest number of new participants at the second meeting of the process came from Africa and Latin America. ${ }^{86}$ At that meeting, South Africa’s Archbishop Desmond Tutu extolled African leadership on banning land mines and called for "similar leadership in this process to eliminate cluster munitions."87

Regional meetings in Africa and Latin America were key stepping-stones in the negotiations and sites for forging common regional positions. NGOs used the meetings to shape the international roles of countries and to minimize action of reluctant states that would be at odds with their region's position. The African conference was important because most African countries hadn’t participated in prior CCW meetings and lacked 
detailed knowledge of the CM problem. According to one NGO member, the goal of the conference was to educate government officials about the issues and to "empower them to play a more active role in the Oslo Process.” 88

Regarding land mines, African countries were presented as mine-affected countries in which people fell victim to mines manufactured elsewhere and that had the right to be heard in the negotiations. On CMs, where African contamination was much lower, NGOs and UN agencies spoke of the need for African states to act preventively to ensure that they didn’t become “once again the dumping ground of weapons considered obsolete in other places.” This argument would be a core justification for the African position favoring a strong ban. ${ }^{89}$ Campaigners and pro-ban diplomats also invoked Africa’s essential role in the prior land mine process to encourage a similar role on cluster munitions, ${ }^{90}$ a point emphasized in the resulting Livingstone Declaration of the African regional conference. ${ }^{91}$

The campaign resonated with the interest in peace and disarmament shared by some African countries, including Zambia, which assumed leadership in coordinating the African position ${ }^{92}$-leadership expected to strengthen its image as a "good international citizen."93 The campaign also appealed to many African countries’ spirit of independence, instigating the desire to stand up to the big powers that weren’t participating in the process or were holding it back. NGOs sought to invoke this same spirit to gain support for the Oslo Process and to highlight that its success depended on African strength. In the words of the CMC coordinator, Thomas Nash, “Africa has now an opportunity to stand as a bulwark against the efforts of certain states-mainly producers and stockpilers - to weaken the treaty. 'Right now we need Africa’s strength, wisdom and united voice to ensure we get a treaty with no exemptions, no delays and no loopholes." ${ }^{94}$ CMC projected a pivotal role onto African states, arguing, “Too often Africa’s voice is pushed to the margins in international 
decision making. But in banning cluster bombs worldwide, a common African voice will speak volumes and win the day." ${ }^{95}$ Campaigners also publicly put themselves in a collaborative but dependent relationship with those states. Nash argued, "We have always relied on African countries in this campaign. Now that we are on course, we will still rely on them to come up with a comprehensive position on this issue.”96

At the same time, NGOs worked patiently to cultivate the positions of African countries. When countries had difficulty formulating a stance on technical issues, NGOs gave them extensive information as well as expert and legal opinions. ${ }^{97}$ The CMC became a point of reference for many developing countries, which made ban opponents complain that “countries in Africa and central and Latin America were only doing what the NGOs told them."98

At the final conference in May 2008, African and other developing states were key in maintaining the treaty's strength in the face of attempts by the UK and other likeminded states to insert exceptions from the CM definition and to add transition periods allowing the use of otherwise banned munitions. ${ }^{99}$ Zambia’s main negotiator and coordinator of the African group, Sheila Mweemba, summed up the confrontation with ban opponents and Africa’s role, saying, "It is little wonder that those who were against a convention of this sort are still reeling from the shock of it. Africa, on the other hand, can give itself a welldeserved pat on the back for having played a pivotal role in the adoption of a groundbreaking, legally binding instrument." ${ }^{100}$ And in his address to parliament overviewing 2008 activities, Zambian Minister of Foreign Affairs Kabinga Pande noted the leadership credentials Zambia gained through its "significant role in the conclusion of a groundbreaking international humanitarian treaty” and its election as the African coordinator and host of the Livingstone meeting, which "signalled Africa’s strong 
opposition to cluster munitions.” He pointed out that “Zambia’s role in the process raised her international profile.”101

In the run-up to the treaty signing, NGOs and core states organized another conference, in Uganda, and continued to praise African past leadership and encourage active African involvement. ${ }^{102}$ Ultimately, sub-Saharan African states made up 36 percent of the signatories at the signing ceremony.

African states were also pivotal when, three years after CCM’s adoption, they closed ranks with leaders of the Oslo Process, including Norway, Austria, and Mexico, to withstand US attempts to adopt a new, much weaker CCW protocol that would have legitimized continued use of CMs already banned by the CCM. ${ }^{103}$ On CMs, they were the moral leaders establishing a norm rather than simply states joining the club of those in good international standing. Moreover, they were the states that together with the core group maintained the momentum behind the early norm cascade: "the treaty existence hinged upon African and Latin American support—-their leadership was key to its success.”104

African states also played important roles in the land mine process and became a focal point for the ICBL campaign. To expand its coalition network in Africa, the ICBL organized several conferences aimed at catalyzing support for the land mine ban ${ }^{105}$ with South Africa as a particular focus of the budding African campaigns. ${ }^{106}$ Early on, South Africa was portrayed as taking “a leadership role in Africa on the landmines issue” after the government of F. W. de Klerk committed to an export moratorium in 1994 (later upheld by the Nelson Mandela government). ${ }^{107}$ NGOs saw that step as significant because of South Africa’s past of suppling mines in the region. ${ }^{108}$ With Mandela in power, South Africa committed to being a responsible global citizen and promoting human rights, justice, and respect for international law, including arms-control agreements. ${ }^{109}$ Thus it was expected 
that South Africa would also "seize the moral high ground ... and support an all-out ban.” ${ }^{110}$ From an NGO conference in Cambodia, amputees sent Mandela a letter "urging him to be involved in the ban," 111 and Tutu called for African support for a comprehensive prohibition at a conference organized by the International Committee of the Red Cross and the Organization of African Unity (OAU) in March 1995. ${ }^{112}$

Nevertheless, in September 1995 at the CCW, the South African government announced that it would ban the use of persistent mines but allow the development of self-destructing land mines. NGOS responded with strong criticism and disappointment. Interestingly, the government felt obliged to defend its policy, claiming that South Africa had become "a world leader in the move away from the use of landmines.”"113 Seeking a compromise position that would attract broad support at the CCW, it argued that amending the cCW Protocol would be a "step toward the eventual elimination of landmines." 114 In addition to the lack of support for a total ban among CCW negotiating states, South Africa’s policy was constrained by domestic military insistence on the utility of land mines. Still, NGOs remained optimistic "that we do have a government which will remain open to constructively addressing the landmine issue." ${ }^{115}$ As a whole, the approach of the South African Campaign to Ban Landmines focused on “argu[ing] for something as opposed to against something” and “acknowledg[ing] and prais[ing] progress.”116 Indeed, in May 1996, South Africa moved forward by expressing support for "efforts to achieve an international prohibition on the production, stockpiling, transfer and use of all anti-personnel land-mines,” making its export moratorium permanent and suspending all use of land mines by its defense forces while awaiting a report on their military utility. ${ }^{117}$ South African NGOs welcomed these steps but prodded the government to act further, arguing that there would be a "contradiction that they support a total ban 
eventually, yet fail to legislate it in South Africa." ${ }^{118}$ In an attempt to address military opposition and to encourage South African leadership, NGOs also garnered the support of military figures, who asserted that a ban would be "not only humane, but also militarily responsible” and would help the country "set a leading example in Africa.”119 Campaigners argued, "If the South African government is committed to human rights and to promoting peace and development within Southern Africa, it should pass a law banning these weapons." 120

In February 1997, a few days before the first NGO conference on the topic in Africa was to be held in Maputo, Mozambique, the South African government finally announced that it was banning the production, trade, and use of land mines. The decision was attributed to "the diplomatic dividend" to be gained and the realization that South Africa couldn't lead in demining without banning the weapons. ${ }^{121}$ NGOs praised "South Africa’s visionary leadership [as] an important symbol for the world.”122

At the opening of the Maputo conference, Graça Machel, a key supporter of the Mozambican campaign, argued, “Africa, the world’s most heavily mined continent, must take leadership in the campaign to ban these indiscriminate killers.”123 A day later, spurred by the South African ban, Mozambique announced its own land mine ban. The ICBL coordinator, Jody Williams, greeted it with the hope that more South African Development Community countries would "follow the example and take cues from the leadership shown by South Africa and Mozambique.” ${ }^{124}$ In their final conference declaration, NGOs reiterated the call for African states to "follow the lead of Mozambique and take unilateral steps to ban antipersonnel landmines” and "continue to build momentum toward the signing of the Ottawa treaty.”125 
At the following OAU land mine conference, held in May 1997 in South Africa, African NGOS again "call[ed] on their governments to show moral leadership by taking unilateral steps to ban antipersonnel landmines” and to create “a mine-free Southern Africa, as an example for the rest of the continent, and world.”126 Similarly, HRW argued that “southern Africa should take the lead” in Africa and back the Ottawa Process. ${ }^{127}$ African support for a ban was portrayed as part of African independence and a rebirth that would break with negative images of the continent as a place of underdevelopment and conflict, and help Africa assert its place in the world. ${ }^{128}$ On behalf of the African campaigns, Tutu “commend[ed] ... South Africa and Mozambique for their outstanding roles as leaders.” He appealed to African states to commit to the treaty and "have this one little gift to give to the world.” ${ }^{229}$ His message resonated particularly with South Africa, whose approach to land mines was “grounded in internationalism.” The country’s leading role in the process can be seen as part of its post-apartheid trajectory from pariah to "a recognized progressive force” in international society. ${ }^{130}$

At the end of the conference, in a symbolic demonstration of its leadership and partnership with the NGO community, the South African government invited NGO members to a "big bang" ceremony to witness the destruction of its first batch of land mines. ${ }^{131}$ Thus by organizing conferences in African countries, the NGOs not only raised awareness of the issue but also provided leadership opportunities for hosting governments. And, to quote Tutu, they managed to "goad various governments to take appropriate action.” 132 The lead taken by South Africa and Mozambique created momentum for other states in southern Africa to support the Ottawa Process for a total land mine ban. ${ }^{133}$ Just as in the case of CMs, the strength of the MBT depended on the African states' resistance to US attempts to weaken the treaty provisions at the final conference. ${ }^{134}$ South 
Africa also completed destruction of its entire stockpile before signing the MBT (well ahead of the stipulated four-year deadline after the treaty's entry into force, and at an estimated cost of US\$19 million). ${ }^{135}$ NGOs praised this step as “a complement to South Africa’s leadership in negotiating the treaty." 136 In recognition of its leading role along with Canada and Norway, South Africa was the third state to sign the MBT, in December 1997. ${ }^{137}$

Certifying African leadership credentials, African campaigners expressed their pride in "those African governments who have taken a leadership role" and "urge[d] all African governments to be among the first 40 countries to ratify the treaty." ${ }^{138}$ In a congratulatory letter to African leaders, Machel reiterated NGOs' pride “that the plea made in South Africa by Archbishop Tutu that Africa help give the world the gift of a total ban on landmines has been heard throughout the continent, and indeed world.” Campaigners went on to praise the African governments "that were exemplary in their consistent resistance to US pressure.”139

\section{Negative Altercasting of Dominant States to MobiLize the Rest}

Juxtaposing the good and the bad states combined with the inconsistent or openly adversarial position of the United States resulted in NGOs painting the US as a retrograde force supporting the use of inhumane weapons - even though US policies were more progressive than those of ban opponents like China and Russia. The United States had initially supported a mine ban, acknowledged the CM humanitarian problem, and generally embraced humanitarian norms; these actions opened it to NGO shaming for its failure to live up to its rhetorical commitments.

For NGOs, focusing on the United States made sense to increase issue salience. It also ensured that NGOs were perceived as impartial rather than subservient to big 
powers - a factor that has influenced the development of HRW, ${ }^{140}$ a leading NGO in both campaigns. Accordingly, HRW's international humanitarian law reporting was shaped by the concern not to appear as "a Western, imperialist organization defending the interests of the US.” ${ }^{141}$ Involving local organizations was another way to enhance NGOs’ acceptance by states that may otherwise regard them as extensions of dominant states’ policies. Finally, the often exceptionalist positions of the United States, along with its aggressive lobbying practices, provided the backdrop against which NGOs projected a progressive role for other states. Thus, negative altercasting of dominant states enhanced the effects of positively altercasting norm leaders.

The appeal for African leadership on land mines resonated because initially the UN Security Council members didn’t participate in the Ottawa Process, which “increased its credibility” among countries from the South. ${ }^{142}$ According to Leon Sigal, "Identifying the 'sole superpower' with opposition to a landmines ban inspired others to favor it,” especially in the context of the African regional meetings. ${ }^{143}$ Williams, the ICBL coordinator, spearheaded its strategy: "Using the United States as a foil, [she] mobilized support in the rest of the world," "stigmatiz[ing] the United States as a way of getting other countries on the treaty." 144 It could only help that "distrust of the United States was endemic among many [ICBL] affiliates.” ${ }^{145}$ Charting a course independent from that of the United States solidified support for the ban among developing countries. ${ }^{146}$

Whether leading states actively partook in negatively altercasting the United States is less clear. According to a Canadian diplomat, one part of its Ministry of Foreign Affairs used the strategy: "We knew ... we could make the argument to Gabon, Jamaica, South Africa that this is something the United States wouldn't do and we could make the United States look bad.” ${ }^{147}$ According to another government official, their overall idea 
was "to build up a norm by numbers and practice." Big states like the United States were "nice to have, but not necessary"; it was expected that they would be shamed into compliance once the norm was established. US opposition didn't impede the Canadians from pushing the process forward because a "swarm" of other countries supported it. ${ }^{148}$

There was "delight among states that Canada managed to drive the process forward without the US.” Apparently, "states were awed at the energy and success” of the process, with some, such as South Africa, an aspiring big power, willing to stand up to the United States. But while Canada was concerned about bilateral relations and diplomatic practice, NGOS could openly attack the US position—“they were, like, let’s stick it to the US, let's go, whatever." ${ }^{149}$ Given the division of labor between ICBL and core-group governments and the fact that Canadian officials worked "hand-in-glove with Jody [Williams]”150 and "particularly closely” with HRW’s Steve Goose, the other key person in the NGO campaign, ${ }^{151}$ there was likely a tacit agreement between NGOs and Canadian officials to capitalize on American opposition. ${ }^{152}$

The Canadian lead came into high relief against the US position. President Bill Clinton was portrayed as "stranded in a minefield of his own: left behind by a fastmoving Canadian foreign policy initiative.” According to HRW, the United States was left with "ruffled feathers," "uncomfortable that middle and small powers are driving [the process]." ${ }^{153}$ And once the US decided to participate in the negotiations, HRW blasted its position as one of "bad faith" due to its demands for accommodations. ${ }^{154}$

By denouncing the United States for working behind the scenes or openly pressuring states to weaken the treaty, NGOs limited the actions of ambivalent states in the processes - they could either stand up for a strong treaty or be portrayed as subservient to the US. Thus, in the CM process NGOs denounced states that demanded the inclusion of 
language that would ensure the legality of their armed forces' participation in joint operations with nonstate parties, citing their "hypocrisy" and saying they were “appeas[ing] the US” and doing its “dirty work." 155 On land mines, NGOs even accused Canada of "selling out" to the United States, ${ }^{156}$ calling it "the 51st USA state" when it tried to accommodate some US demands. ${ }^{157}$ In turn, such shows of weakness required NGOS to cast developing countries as the norm stalwarts, and "stiffened the backs of the delegates” in the final negotiation. ${ }^{158}$ African states had been placed in a pivotal role before the Oslo conference started, when the Norwegians did the "smart thing" and gave the chair to South Africa, aiming to "get more countries involved" and to acquire a "solid Third World support” that the "four leading countries with little military credibility" needed. ${ }^{159}$ In the wake of the negotiations, campaigners could "feel proud to be African" and could offer praise to "African governments [that] consistently defended the integrity and spirit of the ban treaty text by preventing attempts by the USA to gut [it].”160

To US diplomats, the land mine process targeted the US, with states discounting its legitimate military interests and responsibilities, especially in South Korea. ${ }^{161}$ According to Clinton, the final conference was determined to pass "the strongest possible treaty ... partly because some people at the conference just wanted to embarrass the United States or bully us into signing the treaty as it was.” ${ }^{162}$ Despite Clinton's interest in joining the treaty, the US's late and inconsistent policies made it an easy target for negative altercasting. Ultimately, its contradictory stance led to its isolation and stigmatization during the negotiations, effectively turning the process into "a US-or-them affair."163

On CMs, the fact that major states preferred the CCw go-slow forum "probably contributed to many states, especially in the developing world ... taking a greater interest 
in participating in the Oslo Process." ${ }^{164}$ In contrast to the land mine case, the United States took no part in the Oslo Process. Keeping a lower profile, it held talks with allies about the process, but core-group diplomats say that despite US officials' decrying the process as "outrageous," the CM negotiations never gained political prominence. Nor did Secretary of State Condoleezza Rice ever raise the topic with the Norwegian foreign minister. ${ }^{165}$

Hence, the main NGO target became the other big countries that were reluctantly participating in the process, especially the UK. According to one core-group diplomat, "The UK played the role of the US in the Oslo Process and played it very badly." At the penultimate conference in Wellington, New Zealand, the UK accused developing states of "not understanding the issues and having nothing to do in the negotiations," which turned the process into "a North-South issue." Thus, for core states, the UK became "the best enemy [they] could have hoped for.” ${ }^{166}$ When the UK and a group of Western states attempted to push for exclusions in the treaty draft, developing states formed a Friends of the Affected States group that urged the core group to "stand firm." 167

At the penultimate conference, CMC activists greeted the UK and likeminded states, such as France, Japan, and Germany, with "Shame on you!” posters, ${ }^{168}$ and accused them of "exerting diplomatic pressure to weaken the draft treaty," "protect[ing] their own stockpiles," 169 and seeking to weaken the draft treaty "to allow the US to continue using cluster munitions." ${ }^{170}$

The tactic of core states and NGOs to attract staunch supporters from developing countries caused UK diplomats to smart—aggravated by the increasing role of developing countries, by constant NGO critiques, and by their own inability to influence the process. Similar to the US emphasis on its exceptional position, the UK responded by 
asserting its global role and contributions to peace and security. ${ }^{171}$ The British overreacted in dismissing "the equity" of smaller states to influence the process, which, according to an African diplomat, could have contributed to some of the Friends of the Affected States "digging in their heels." ${ }^{\text {"172 }}$ The UK thus became a perfect target for NGO criticisms—-the "best enemy" that helped to mobilize developing states.

Even in this case, the United States managed to draw fire to itself precisely when the UK was reorienting its policy toward fully supporting the Oslo Process. As NGOS shifted from criticizing UK policies to mostly encouraging and praising its leadership, the United States became a substitute target. At the final conference, UK Prime Minister Gordon Brown publicly instructed negotiators to "work intensively to ban cluster bombs," a message that marked a major policy change toward favoring a strong treaty. ${ }^{173}$ The same day, the US State Department held a briefing on CM policy. Stressing that the United States was “deeply concerned about the humanitarian impact” of CMs, it highlighted American clearance operations but voiced concerns about joint operations, asserting that "if the convention passes in its current form, any US military ship would be technically not able to get involved in a peacekeeping operation, in providing disaster relief or humanitarian assistance.” ${ }^{174}$ NGOs responded by accusing the United States of "unacceptable blackmail,"175 "bullying," and "cynically” trying to "intimidate the countries that are negotiating in good faith.” 176 The CMC organized a protest rally in front of the US embassy and a panel on the US position at the conference. There, Williams called the United States the "elephant not in the room that everyone is doing a ballet around," arguing that the US "had talked to at least 114 states" and a strong treaty was better even if several states walked away. ${ }^{177}$ 
Thus small, especially African, states were called upon to withstand US pressure—a role they assumed and were cheered for taking. In the words of Handicap International regarding the penultimate conference of the Oslo Process, "Just like it happened during the anti-personnel landmine process, we are seeing that when southern countries ... are united they have the power to successfully challenge the domination of producer states who normally make the rules." 178

\section{NORM ROBUSTNESS AND WEAPON STIGMATIZATION}

A question remains about the extent to which norms banning weapons actually take hold when shunned by major military powers. From the beginning, NGOs have argued that their objective is to stigmatize the weapons and to press countries outside the treaties into norm compliance. It's been demonstrated that nonstate parties, particularly the United States, have complied with the MBT norms of no production, trade, or use of land mines. ${ }^{179} \mathrm{I}$ briefly show a similar trend regarding CMs in three hard cases for the impact of stigmatization—-the United States, ${ }^{180}$ Israel, and Russia.

The United States may insist that it doesn't accept that the CCM establishes a new, legal norm and that CMs remain "a legitimate weapon when used appropriately,” ${ }^{181}$ but in practice it has responded in ways that support the existence of the norm. In May 2008, the Pentagon issued a policy recognizing "the need to minimize the unintended harm to civilians and civilian infrastructure associated with unexploded ordnance of cluster munitions.” It directed that all CMs used after 2018 should result in "no more than 1\% unexploded ordnance," and before that date the use of cMs exceeding that failure rate had to be approved high in the command chain by the Combatant Commander. ${ }^{182}$ Because that 
1 percent criterion was hard to meet, the US has produced no CMs since then, apart from sensor-fuzed weapons that met the criterion on paper. ${ }^{183}$ Domestically, US senators have pushed through a ban on the export and transfer of CMs with a dud rate above 1 percent, ${ }^{184}$ which stopped US exports of all CMs except sensor-fuzed weapons. But after an outcry against Saudi Arabia's use of American sensor-fuzed weapons, President Barack Obama halted the export of these weapons in mid-2016. ${ }^{185} \mathrm{~A}$ few months later, their manufacturer ceased production due to "reduced orders, a volatile political environment, and international weapons treaties that negatively affect the 'ownability' of its shares.” ${ }^{186}$ This effectively ended all US production of CMs. ${ }^{187}$

Since 2003 the US has allegedly used CMS only once, in a 2009 strike against an alQaeda camp in Yemen that caused numerous civilian casualties. ${ }^{188}$ Despite NGO questions, the US has never issued an official response to these allegations. Rather than undermining the new norm, this attempted concealment of breaching behavior could be seen as an indication of the norm's influence. ${ }^{189}$

In addition, between 2013 and 2017, the United States voted for resolutions by the UN General Assembly and the Human Rights Council condemning the use of CMs by the Syrian government, voted for a UN Security Council resolution expressing concern over CM use in South Sudan, and several times voiced concern about CM use in Ukraine. ${ }^{190}$ Thus, the United States felt the stigma of CMs and de facto stopped their use, production, and export by 2016. Rhetorically, the United States has also reinforced the norm against CMs.

Israel, a country in a complex security environment that has produced and used CMs, is another hard case. After using CMs in Lebanon in 2006, Israel insisted, "both international law and accepted practice do not prohibit use." ${ }^{191}$ Until mid-2008, it 
consistently argued that international humanitarian law provisions were sufficient to regulate CM use. Still, in 2009, Israel indicated that it "shares the views of those states wishing to alleviate the humanitarian concerns that may be associated with the use of cluster munitions." ${ }^{192}$ Importantly, Israel's investigation of the conduct of the Lebanon War concluded that general IHL principles implied a "prohibition or limitation of cluster fire at locations in which there are concentrations of civilian population" and that "use of cluster bombs must also take into account injury from unexploded bomblets long after they are fired. ${ }^{193}$ In 2012, an Israeli military official argued that in a future war, CM use would be "significantly reduced" due to considerations including "legitimacy, our non-indifference to the treaty.”" 194 In practice, Israel hasn’t used CMs since 2006, despite heavy military operations in Gaza, and has voted for UN resolutions condemning CM use in Syria. ${ }^{195}$

Russia presents the hardest test of CM stigmatization, given the country's resistance to liberal norms, limited domestic NGO influence, and adamant opposition to legal restrictions on CMs. Still, in November 2008, Russia joined the view that CMs "pose a serious humanitarian danger," and subsequently acknowledged "the use of cluster munitions ... in recent years has had serious negative consequences.” ${ }^{196}$ These statements indicated that at least rhetorically, Russia had begun to accept that CMs are problematic weapons.

In practice, Russia used CMs in Georgia right after the CCM adoption in 2008, and Russian-backed forces allegedly used CMs in Ukraine in 2014-15. But Russia hasn't acknowledged any use to date. Moreover, Russia has rhetorically accepted the existence of an international norm against CMs and used it to score political points in the conflict with Ukraine. Russia was the first state to raise the issue of CM use in Ukraine in the Organization for Security and Cooperation in Europe, and the first to point to the use of 
“prohibited munitions, including cluster bombs” in UN Security Council debates. In addition, highlighting the stigma carried by CMs, a Russian spokesperson argued that Ukraine’s CM use showed the "barbaric nature" of its military operations. ${ }^{197}$ After the start of Russia’s campaign in Syria, HRW and Amnesty International reported increased CM use. ${ }^{198}$ Russia quickly denied that it possessed or employed CMs in Syria, and used the occasion to challenge Amnesty International for being silent on the "irrefutable evidence of usage of cluster bombs by the Ukrainian Armed Forces.” ${ }^{199}$ After HRW produced evidence of Russian aircraft carrying CMs in Syria, ${ }^{200}$ Russia shifted to neither confirming nor denying their use. But CM use in Syria increased significantly in 2017. Although Russia maintained, "No cases of indiscriminate use of air weapons have been registered," ${ }^{201} \mathrm{HRW}$ continues to document indiscriminate air strikes, including by CMs. ${ }^{202}$ Although it doesn't outright reject the CM norm and its underlying IHL principles, Russia’s behavior is still a challenge. To the extent that Russia distances itself from international liberal values, it is an outsider's challenge, the detrimental effects of which can be limited. Indeed, criticism of Russian CM use could strengthen commitment to the norm among states that identify as good international citizens.

Although major military powers embroiled in armed conflict remain outside the treaty, there are indications that they tacitly acknowledge the existence of the norm against CMs, and have even used it rhetorically for political purposes—a first step toward norm acceptance. Importantly, the United States-the power at the center of the international normative order—has largely complied with the new norm. This gives grounds to argue that the normative cascades stigmatizing land mines and CMs are not only swift, but so far also largely robust. 


\section{CONCLUSION}

This article illuminates an important but largely unexplored aspect of norm development. Whereas scholars conceptualize norm cascades as norm diffusion processes resulting from peer pressure and emulation, I argue that at an earlier stage of norm development and treaty making, we can also witness the unfolding of a cascade of state support for an emerging norm, albeit one driven by different social mechanisms—status seeking and positive altercasting. I suggest some scope conditions under which such fledgling norm cascades occur when active NGO and state involvement is present. Positive altercasting can be effective in cases when target actors feel status deficit, when the altercasters are not dominant but are legitimate actors, and when positive altercasting of weaker actors is combined with negative altercasting of dominant ones.

Important questions remain. Do such norm cascades strengthen or fragment the international legal order? Do they undermine US legitimacy and leadership? How should the United States respond in the face of similar initiatives that haven’t abated? ${ }^{203}$

I argue that nonhegemonic norms have far-reaching effects on important nonsignatories. As such, they weave the fabric of international law and sustain the institutions of international order. I also show that they simultaneously undermine the legitimacy of the US hegemonic position. Such initiatives both respond to US distancing from international institutions and, in the short term, contribute to US isolation. The longterm effect sought by norm entrepreneurs is to enmesh the United States back into the international normative web. They have been relatively successful so far, but the balance between short- and long-term consequences is precarious. As norm proponents capitalize on US opposition to emerging norms and cast the US as a pariah, they corrode the 
country's legitimacy and ability to lead. The unintended consequence may be to unravel US hegemony and to destabilize the international liberal order.

To avoid this scenario, the United States should seek to engage in normative development early on to ensure that its interests are taken into account. It should also better evaluate its own limits to achieve those interests and adapt its policy accordingly. In view of the above cases, it may be worthwhile for the United States to assume some short-term costs, accommodate status seeking, and foster state equality rather than US exceptionalism to maintain its position at the helm of a consent-based international order—something scholars have long advocated against the lure of asserting American self-interest pure and simple. ${ }^{204}$

SUPPLEMENTARY MATERIAL

Supplementary material for this article can be found at doi: 10.1017/S0043887tktk.

\section{REFERENCES}

Acharya, Amitav. 2004. "How Ideas Spread: Whose Norms Matter? Norm Localization and Institutional Change in Asian Regionalism.” International Organization 58, no. 2: 239-75. doi:10.1017/S0020818304582024.

Adler-Nissen, Rebecca. 2014. "Stigma Management in International Relations: Transgressive Identities, Norms, and Order in International Society.” International Organization 68, no. 1: 143-76. doi: 10.1017/S0020818313000337.

Amnesty International. 2010. "Yemen: Images of Missile and Cluster Munitions Point to US Role in Fatal Attack.” Press Release, June 7. At https://web.archive.org/web/20100609220159/http://www.amnesty.org/en/formedia/press-releases/yemen-images-missile-and-cluster-munitions-point-us-rolefatal-attack-2010-, accessed May 10, 2018.

Amnesty International. 2015. “Russia’s Bombing in Syria Has Killed Hundreds of Civilians—New Report.” Press Release, December 23. At 
https://www.amnesty.org.uk/press-releases/russias-bombing-syria-has-killedhundreds-civilians-new-report, accessed May 10, 2018.

Bailey, Jennifer L. 2008. "Arrested Development: The Fight to End Commercial Whaling as a Case of Failed Norm Change.” European Journal of International Relations 14, no. 2: 289-318. doi: 10.1177/1354066108089244.

Borrie, John. 2009. Unacceptable Harm: A History of How the Treaty to Ban Cluster Munitions Was Won. UN Institute for Disarmament Research (series). New York, N.Y.: United Nations Publications.

Bower, Adam. 2015. "Norms without the Great Powers: International Law, Nested Social Structures, and the Ban on Antipersonnel Mines.” International Studies Review 17, no. 3: 347-73. doi: 10.1111/misr.12225.

Brem, Stefan, and Kendall Stiles, eds. 2009. Cooperating without America: Theories and Case Studies of Non-Hegemonic Regimes. London, UK, and New York, N.Y.: Routledge.

Busby, Joshua W. 2010. Moral Movements and Foreign Policy. Cambridge, UK: Cambridge University Press.

Cassese, Antonio. 1986. International Law in a Divided World. Oxford, UK: Clarendon Press.

Checkel, Jeffrey T. 2001. "Why Comply? Social Learning and European Identity Change.” International Organization 55, no. 3: 553-88. doi: 10.1162/00208180152507551.

Cilliers, Jakkie. 1997. "South Africa and the International Campaign to Ban Anti-Personnel Landmines.” African Security Review 6, no. 1: 5-15. doi:

10.1080/10246029.1997.9627692.

Clinton, Bill. 2004. My Life. New York, N.Y.: Alfred A. Knopf.

Cluster Munition Coalition. 2008a. "Global Push to Ban Cluster Bombs at Crossroads: Governments Called Upon to Keep Protection of Civilians at Forefront of Negotiations.” Press release, February 18. At https://reliefweb.int/report/world/global-push-ban-cluster-bombs-crossroadsgovernments-called-upon-keep-protection, accessed April 2, 2018.

Cluster Munition Coalition. 2008b. "Nine Governments Seek to Weaken Draft Treaty to Allow US to Continue Using Cluster Munitions.” Press release, February 19. At 
http://web.archive.org/web/20080307004000/http://www.stopclustermunitions.org/ne ws.asp?id=114, accessed July 24, 2018.

Cluster Munition Coalition. 2008c. “A Strong African Voice Is Needed.” Press Release, March 31. At http://www.stopclustermunitions.org/en-gb/media/news/2008/a-strongafrican-voice-is-needed.aspx, accessed June 6, 2018.

Cluster Munition Coalition. 2008d. “Campaigners Call On U.S. to Stop Bullying Negotiators.” Press release, May 23. At http://www.stopclustermunitions.org/engb/media/news/2008/campaigners-call-on-us-to-stop-bullying-neg.aspx, accessed June 6, 2018.

Cluster Munition Coalition. 2008e. “Africa Continues to Lead the Way on Cluster Bomb Ban.” September 29. At http://www.stopclustermunitions.org/engb/media/news/2008/africa-continues-to-lead-the-way-on-cluster-b.aspx, accessed June 6, 2018.

Cluster Munition Coalition. 2008f. “What Is Prohibited?” Presentation by Richard Moyes, Kampala Conference on Cluster Munitions, September 29. At http://web.archive.org/web/20140430052544/http://www.stopclustermunitions.org/w p/wp-content/uploads/2008/10/kampala-conference-presentation-r-moyes.pdf, accessed March 5, 2017.

Cluster Munition Coalition. 2010. "US: Confirm or Deny Use of Cluster Munitions in Yemen.” June 8. At http://www.stopclustermunitions.org/en-gb/media/news/2010/us-confirm-ordeny-use-of-cluster-munitions.aspx, accessed May 8, 2018.

Cluster Munition Monitor. 2012. Report. At http://www.themonitor.org/media/1640044/Cluster_Munition_Monitor_2012.pdf, accessed May 12, 2018.

Cluster Munition Monitor. 2017. Report. At http://www.themonitor.org/media/2582190/Cluster-Munition-Monitor-2017_web4.pdf, accessed July 7, 2018.

Cole, Wade M. 2005. "Sovereignty Relinquished? Explaining Commitment to the International Human Rights Covenants, 1966-1999.” American Sociological Review 70, no. 3: 472-95. doi: 10.1177/000312240507000306. 
Comstock, Audrey L. 2019. “Adjusted Ratification: Post-Commitment Actions to UN Human Rights Treaties,” Human Rights Review 20, no. 1: 23-45. doi: 10.1007/s12142-018-0536-0.

Cooper, Andrew F., John English, and Ramesh Thakur, eds. 2002. Enhancing Global Governance: Towards A New Diplomacy? Tokyo, Japan: United Nations University Press.

Cortell, Andrew P., and James W. Davis Jr. 2000. “Understanding the Domestic Impact of International Norms: A Research Agenda.” International Studies Review 2, no. 1: 6587. doi: 10.1111/1521-9488.00184.

Cottrell, M. Patrick. 2009. “Legitimacy and Institutional Replacement: The Convention on Certain Conventional Weapons and the Emergence of the Mine Ban Treaty.” International Organization 63, no. 2: 217-48. doi: 10.1017/S0020818309090079.

Cottrell, M. Patrick. 2016. The Evolution and Legitimacy of International Security Institutions. New York, N.Y.: Cambridge University Press.

Crawford, Neta C. 2002. Argument and Change in World Politics: Ethics, Decolonization, and Humanitarian Intervention. Cambridge, UK: Cambridge University Press.

Dube, Gugu. 2009. “Negotiating the Convention on Cluster Munitions: The Role of African States.” ISS Paper 187. Tshwane, South Africa: Institute for Security Studies. At https://www.issafrica.org/uploads/Paper187.pdf, accessed July 30, 2018.

Dube, Gugu, and Noel Stott. 2008. “Africa to Set the Pace of New Convention on Cluster Munitions.” October 23. At https://www.issafrica.org/iss-today/africa-to-set-the-paceof-new-convention-on-cluster-munitions, accessed July 30, 2018.

Erickson, Jennifer L. 2015. Dangerous Trade: Arms Exports, Human Rights, and International Reputation. New York, N.Y.: Columbia University Press.

Farrell, Henry, and Martha Finnemore. 2013. “The End of Hypocrisy: American Foreign Policy in the Age of Leaks.” Foreign Affairs 92, no. 6: 22-26. At https://www.jstor.org/stable/23527009, accessed April 1, 2019.

Finnemore, Martha. 2009. “Legitimacy, Hypocrisy, and the Social Structure of Unipolarity: Why Being a Unipole Isn’t All It's Cracked Up to Be.” World Politics 61, no. 1: 5885. doi: 10.1017/S0043887109000082. 
Finnemore, Martha, and Kathryn Sikkink. 1998. “International Norm Dynamics and Political Change.” International Organization 52, no. 4: 887-917. doi: 10.1162/002081898550789.

Gates, Robert M. 2008. Memorandum from the Secretary of Defense. Subject: DoD Policy on Cluster Munitions and Unintended Harm to Civilians.” June 19. At https://www.globalsecurity.org/military/library/policy/dod/d20080709cmpolicy.pdf, accessed June 30, 2018.

Gecas, Viktor. 1982. “The Self-Concept.” Annual Review of Sociology 8: 1-33. doi: 10.1146/annurev.so.08.080182.000245.

Goffman, Erving. 1959. The Presentation of Self in Everyday Life. New York, N.Y.: Anchor. Goose, Steve. 2004. “Cluster Munitions: Toward a Global Solution.” HRW World Report, January. At https://www.hrw.org/legacy/wr2k4/12.htm\#_Toc58744961, accessed March 1, 2018.

Granovetter, Mark. 1978. “Threshold Models of Collective Behavior.” American Journal of Sociology 83, no. 6: 1420-43. doi: 10.1086/226707.

Greenhill, Brian, and Michael Strausz. 2014. "Explaining Nonratification of the Genocide Convention: A Nested Analysis.” Foreign Policy Analysis 10, no. 4: 371-91. doi: 10.1111/fpa.12013.

Gurowitz, Amy. 2006. “The Diffusion of International Norms: Why Identity Matters.” International Politics 43, no. 3: 305-41. doi: 10.1057/palgrave.ip.8800145.

Hafner-Burton, Emilie M. 2012. “International Regimes for Human Rights” Annual Review of Political Science 15: 265-86. doi: 10.1146/annurev-polisci-031710-114414.

Hathaway, Oona A. 2007. “Why Do Countries Commit to Human Rights Treaties?” Journal of Conflict Resolution 51, no. 4: 588-621. doi: 10.1177/0022002707303046.

Hudson, John. 2016. “White House Blocks Transfer of Cluster Bombs to Saudi Arabia.” Foreign Policy, May 27. At https://foreignpolicy.com/2016/05/27/exclusive-whitehouse-blocks-transfer-of-cluster-bombs-to-saudi-arabia/,_accessed May 3, 2018.

Human Rights Watch. 1997. "Human Rights Watch Calls for Mine Free Zone in Southern Africa.” May 20. At http://www.africa.upenn.edu/Urgent_Action/apic_52097.html, accessed May 25, 2018. 
Human Rights Watch. 2015. “Russia/Syria: Extensive Recent Use of Cluster Munitions.” December 20. At https://www.hrw.org/news/2015/12/20/russia/syria-extensiverecent-use-cluster-munitions,_accessed July 4, 2018.

Human Rights Watch. 2016. “Russia/Syria: Daily Cluster Munition Attacks.” February 8. At https://www.hrw.org/news/2016/02/08/russia/syria-daily-cluster-munition-attacks, accessed July 4, 2018.

Human Rights Watch. 2017. "Russia/Syria: Deadly Airstrikes on Trapped Civilians.” October 31. At https://www.hrw.org/news/2017/10/31/russia/syria-deadly-airstrikestrapped-civilians, accessed July 5, 2018.

Human Rights Watch. 2018. "Russia Backs Syria in Unlawful Attacks on Eastern Ghouta.” March 18. At https://www.hrw.org/news/2018/03/18/russia-backs-syria-unlawfulattacks-eastern-ghouta, accessed August 6, 2018.

Human Rights Watch, Landmine Action, Landmine Monitor, International Campaign to Ban Landmines, and Cluster Munition Coalition. 2009. “Banning Cluster Munitions: Government Policy and Practice.” Report, May. At http://www.themonitor.org/media/1641916/banning_cluster_munitions_2009.pdf, accessed May 2, 2018.

Ikenberry, G. John. 2001. After Victory: Institutions, Strategic Restraint, and the Rebuilding of Order after Major Wars. Princeton, N.J.: Princeton University Press.

International Campaign to Ban Landmines. 1994. "Second NGO Conference on Landmines: Conference Final Report.” Geneva, Switzerland, May.

International Campaign to Ban Landmines. 1995a. “The Human and Socio-Economic Impact of Landmines: Towards an International Ban.” Final Report, International Landmines Conference, Phnom Penh, Cambodia, June 2-4.

International Campaign to Ban Landmines. 1995b. "Report on Activities: Review Conference of the Convention on Conventional Weapons.” Vienna, Austria, September 25-October 13.

International Campaign to Ban Landmines. 1996. "Report on Activities: Review Conference of the Convention on Conventional Weapons.” Geneva, Switzerland, April 22-May 3.

International Campaign to Ban Landmines. 1997a. "Fourth International NGO Conference on Landmines.” Report. Maputo, Mozambique, February 25-28. 
International Campaign to Ban Landmines. 1997b. "Report on Activities: Diplomatic Conference on an International Total Ban on Anti-Personnel Landmines.” Oslo, Norway, September 1-18.

Jensen, Steven L. B. 2016. The Making of International Human Rights: The 1960s, Decolonization and the Reconstruction of Global Values. Cambridge, UK: Cambridge University Press.

Katzenstein, Peter J. 1996. “Introduction: Alternative Perspectives on National Security.” In Peter J. Katzenstein, ed., The Culture of National Security: Norms and Identity in World Politics. New York, N.Y.: Columbia University Press.

Keck, Margaret E., and Kathryn Sikkink. 1998. Activists beyond Borders: Advocacy Networks in International Politics. Ithaca, N.Y.: Cornell University Press.

Kelley, Judith. 2008. “Assessing the Complex Evolution of Norms: The Rise of International Election Monitoring.” International Organization 62, no. 2: 221-55. doi: 10.1017/S0020818308080089.

Krasner, Stephen D. 1999. Sovereignty: Organized Hypocrisy. Princeton, N.J.: Princeton University Press.

Krook, Mona Lena, and Jacqui True. 2012. "Rethinking the Life Cycles of International Norms: The United Nations and the Global Promotion of Gender Equality.” European Journal of International Relations 18, no. 1: 103-27. doi: 10.1177/1354066110380963.

Kuran, Timur, and Cass R. Sunstein. 1999. “Availability Cascades and Risk Regulation.” Stanford Law Review 51, no. 4: 683-768.

Landmine and Cluster Munition Monitor. 1999. “South Africa: Mine Ban Policy.” At http://www.themonitor.org/index.php/publications/display?url=lm/1999/south_africa.html_accessed March 6, 2017.

Landmine and Cluster Munition Monitor. 2015a. “Israel: Cluster Munition Ban Policy.” July 21. At http://www.the-monitor.org/en-gb/reports/2015/israel/cluster-munition-banpolicy.aspx, accessed May 30, 2018.

Landmine and Cluster Munition Monitor. 2015b. “Russian Federation: Cluster Munition Ban Policy.” August 10. At http://the-monitor.org/en-gb/reports/2015/russianfederation/cluster-munition-ban-policy.aspx, accessed May 30, 2018. 
Landmine and Cluster Munition Monitor. 2016. "South Africa: Cluster Munition Ban Policy.” August 4. At http://www.the-monitor.org/en-gb/reports/2016/southafrica/cluster-munition-ban-policy.aspx, accessed May 30, 2018.

Landmine and Cluster Munition Monitor. 2017a. "United States: Cluster Munition Ban Policy.” August 4. At http://www.the-monitor.org/en-gb/reports/2017/unitedstates/cluster-munition-ban-policy.aspx, accessed June 6, 2018.

Landmine and Cluster Munition Monitor. 2017b. “Israel: Cluster Munition Ban Policy.” August 3. At http://www.the-monitor.org/en-gb/reports/2017/israel/cluster-munitionban-policy.aspx, accessed June 15, 2018.

Landmine and Cluster Munition Monitor. 2017c. "United States: Mine Ban Policy.” October 23. At http://www.the-monitor.org/en-gb/reports/2017/united-states/mine-banpolicy.aspx, accessed May 10, 2018.

Landmine Monitor. 1999. “Executive Summary.” At http://www.themonitor.org/media/1757245/lm1999execsum.pdf, accessed May 3, 2018.

Landmine Monitor. 2006. “Executive Summary.” At http://www.themonitor.org/media/1682283/Exec-Summary-2006.pdf, accessed April 3, 2018.

Larson, Deborah Welch, T. V. Paul, and William C. Wohlforth. 2014. "Status and World Order.” In T. V. Paul, Deborah Welch Larson, and William C. Wohlforth, eds., Status in World Politics. New York, N.Y.: Cambridge University Press.

Lipson, Michael. 2007. “Peacekeeping: Organized Hypocrisy?” European Journal of

International Relations 13, no. 1: 5-34. doi: 10.1177/1354066107074283.

Lutz, Ellen L., and Kathryn Sikkink. 2000. "International Human Rights Law and Practice in Latin America.” International Organization 54, no. 3: 633-59. doi:

10.1162/002081800551235.

Lutz, Ellen, and Kathryn Sikkink. 2001. "The Justice Cascade: The Evolution and Impact of Foreign Human Rights Trials in Latin America.” Chicago Journal of International Law 2, no. 1: 1-33. At http://chicagounbound.uchicago.edu/cjil/vol2/iss1/3, accessed April 2, 2019.

Mandela, Nelson. 1993. "South Africa’s Future Foreign Policy.” Foreign Affairs 72, no. 5: 86-97.

Markwica, Robin. 2018. Emotional Choices: How the Logic of Affect Shapes Coercive Diplomacy. Oxford, UK: Oxford University Press. 
Maslen, Stuart. 2004. Commentaries on Arms Control Treaties: The Convention on the Prohibition of the Use, Stockpiling, Production, and Transfer of Anti-Personnel Mines and on their Destruction. Oxford, UK: Oxford University Press.

Mbeki, Thabo. 1997. “Address. Thabo Mbeki, Deputy President of the Republic of South Africa.” In Penny McMillin, Jean Lausberg, and Jakkie Cilliers, eds., Towards a Landmine-Free Africa: Proceedings of the First Continental Conference of African Experts on Landmines, 19-21 May. Pretoria, South Africa: Institute for Security Studies.

McMillin, Penny, Jean Lausberg, and Jakkie Cilliers, eds. Towards a Landmine-Free Africa: Proceedings of the First Continental Conference of African Experts on Landmines, 19-21 May. Pretoria, South Africa: Institute for Security Studies. At http://web.archive.org/web/20060225112416/http://www.issafrica.org:80/PUBS/OTH ER/LandmineFree/CONTENT.HTML, accessed April 2, 2019.

Mozambican Campaign Against Landmines. 1997a. “Africa Day of Action Against Landmines: Call to African Governments to Advance on Ottawa.” Press release, October 6. At http://www.africa.upenn.edu/Urgent_Action/dc_111397.html, accessed May 24, 2018.

Mozambican Campaign Against Landmines. 1997b. "Mozambican Campaign Against Landmines Calls on Global Coalition for Africa to Forge a Mine-Free Africa.” Press release, October 31. At http://www.africa.upenn.edu/Urgent_Action/dc_111397.html, accessed May 24, 2018.

Mtonga, Robert. 2007. “Zambia Toasts Global Day of Action to Ban Cluster Munitions.” Times of Zambia. November 8.

Mweemba, Sheila. 2008. “An African Perspective on the Cluster Munitions Convention.” Journal of ERW and Mine Action 12, no. 2: 9-11. At https://commons.lib.jmu.edu/cisr-journal/vol12/iss2/2, accessed April 2, 2019.

Neier, Aryeh. 2012. The International Human Rights Movement: A History. Princeton, N.J.: Princeton University Press.

Nel, Philip, Ian Taylor, and Janis van der Westhuizen. 2000. “Multilateralism in South Africa’s Foreign Policy: The Search for a Critical Rationale.” Global Governance 6, no. 1: 43-60. doi: 10.1163/19426720-00601005. 
Neumann, Iver B. 2002. "Harnessing Social Power: State Diplomacy and the Land-Mines Issue.” In Andrew F. Cooper, John English, and Ramesh Thakur, eds., Enhancing Global Governance: Towards a New Diplomacy? Tokyo, Japan: United Nations University Press.

Neumann, Iver B. 2014. "Status Is Cultural: Durkheimian Poles and Weberian Russians Seek Great-Power Status.” In T. V. Paul, Deborah Welch Larson, and William C. Wohlforth, eds., Status in World Politics. New York, N.Y.: Cambridge University Press.

Neumann, Iver B., and Benjamin de Carvalho. 2015. "Introduction: Small States and Status.” In Benjamin de Carvalho and Iver B. Neumann, eds., Small State Status Seeking: Norway’s Quest for International Standing. Kindle ed. New York, N.Y.: Routledge

Paul, T. V., Deborah Welch Larson, and William C. Wohlforth, eds. 2014. Status in World Politics. New York, N.Y.: Cambridge University Press.

Petrova, Margarita H. 2014. “Small States in Humanitarian Norm Making.” In Louis W. Pauly and Bruce W. Jentleson, eds., Power in a Complex Global System. New York, N.Y.: Routledge.

Petrova, Margarita H. 2016. "Rhetorical Entrapment and Normative Enticement: How the United Kingdom Turned From Spoiler into Champion of the Cluster Munition Ban.” International Studies Quarterly 60, no. 3: 387-99. doi: 10.1093/isq/sqv013.

Petrova, Margarita H. 2018. "Weapons Prohibitions through Immanent Critique: NGOs as Emancipatory and (De)securitising Actors in Security Governance.” Review of International Studies 44, no. 4: 619-53. doi: 10.1017/S026021051800013X.

Petrova, Margarita H. 2019. Supplementary material for "Naming and Praising in Humanitarian Norm Development.” doi: 10.1017/S0043887tktkt.

Phillips, Fred. 2007. “On S-Curves and Tipping Points.” Technological Forecasting \& Social Change 74, no. 6: 715-30. doi: 10.1016/j.techfore.2006.11.006.

Pouliot, Vincent. 2016. International Pecking Orders: The Politics and Practice of Multilateral Diplomacy. Cambridge, UK: Cambridge University Press.

Pratkanis, Anthony. 2000. “Altercasting as an Influence Tactic.” In Deborah J. Terry and Michael A. Hogg, eds., Attitudes, Behavior and Social Context: The Role of Norms and Group Membership. Mahwah, N.J.: Lawrence Erlbaum Associates Publishers, Inc. 
Pratkanis, Anthony R. 2007. The Science of Social Influence: Advances and Future Progress. New York, N.Y.: Psychology Press. doi: 10.4324/9780203818565.

Pratkanis, Anthony R., and Melissa D. Gliner. 2004. “And When Shall a Little Child Lead Them? Evidence for an Altercasting Theory of Source Credibility.” Current Psychology 23, no. 4: 279-304. doi: 10.1007/s12144-004-1002-5.

Price, Richard. 1998. "Reversing the Gun Sights: Transnational Civil Society Targets Land Mines.” International Organization 52, no. 3: 613-44. doi: 10.1162/002081898550671.

Price, Richard. 2004. “Emerging Customary Norms and Anti-Personnel Landmines.” In Christian Reus-Smit, ed., The Politics of International Law. Cambridge, UK: Cambridge University Press. doi: 10.1017/CBO9780511491641.006.

Risse, Thomas, Stephen C. Ropp, and Kathryn Sikkink, eds. 1999. The Power of Human Rights: International Norms and Domestic Change. New York, N.Y.: Cambridge University Press.

Risse, Thomas, Stephen C. Ropp, and Kathryn Sikkink, eds. 2013. The Persistent Power of Human Rights: From Commitment to Compliance. New York, N.Y.: Cambridge University Press.

Russian Ministry of Defence. 2015. “Russian Defence Ministry Commented on Briefing of Amnesty International and Summed Up Results of Operation Carried Out by Russian Aerospace Forces in Syria on December 18-23.” December 23. At http://eng.mil.ru/en/news_page/country/more.htm?id=12072315@egNews,_accessed June 24, 2017.

Rutherford, Kenneth R. 2010. Disarming States: The International Movement to Ban Landmines. Santa Barbara, Calif.: Praeger.

Rutherford, Kenneth R., Stefan Brem, and Richard Matthew, eds. 2003. Reframing the Agenda: The Impact of NGO and Middle Power Cooperation in International Security Policy. Westport, Conn.: Praeger.

Sandholtz, Wayne, and Kendall Stiles. 2008. International Norms and Cycles of Change. Oxford, UK: Oxford University Press.

Schatz, Bryan. 2016. “This American Company Is Finally Getting Out of the Cluster Bomb Business,” Mother Jones. September 1. At 
http://www.motherjones.com/politics/2016/08/textron-cluster-bomb-manufacturerending-production, accessed May 1, 2018.

Schelling, Thomas C. 1971. “Dynamic Models of Segregation.” Journal of Mathematical Sociology 1, no. 2: 143-86, doi: 10.1080/0022250X.1971.9989794.

Schelling, Thomas C. 1978. Micromotives and Macrobehavior. New York, N.Y.: W. W. Norton \& Company.

Schimmelfennig, Frank. 2003. The EU, NATO and the Integration of Europe: Rules and Rhetoric. Cambridge, UK: Cambridge University Press. doi: 10.1017/CBO9780511492068.

Sigal, Leon V. 2006. Negotiating Minefields: The Landmines Ban in American Politics. New York, N.Y.: Routledge.

Sikkink, Kathryn. 2004. "Patterns of Dynamic Multilevel Governance and the InsiderOutsider Coalition.” In Donatella della Porta and Sidney Tarrow, eds., Transnational Protest and Global Activism. New York, N.Y.: Rowman \& Littlefield.

Sikkink, Kathryn. 2011. The Justice Cascade: How Human Rights Prosecutions Are Changing World Politics. New York, N.Y.: W. W. Norton \& Company.

Sikkink, Kathryn. 2017. Evidence for Hope: Making Human Rights Work in the $21^{\text {st }}$ Century. Princeton, N.J.: Princeton University Press.

Smith, Shannon. 2008. "Surround the Cities with the Villages: Universalization of the Mine Ban Treaty.” In Jody Williams, Stephen D. Goose, and Mary Wareham, eds., Banning Landmines: Disarmament, Citizen Diplomacy, and Human Security. New York, N.Y.: Rowman \& Littlefield.

Stott, Noel. 1998. “The South African Campaign.” In Maxwell A. Cameron, Robert J. Lawson, and Brian W. Tomlin, eds., To Walk Without Fear: The Global Movement to Ban Landmines. Toronto, Canada: Oxford University Press.

Sunstein, Cass R. 1996. “Social Norms and Social Roles.” Columbia Law Review 96, no. 4: 903-68. doi: 10.2307/1123430.

Turner, Monique Mitchell, John A. Banas, Stephen A. Rains, SuAhn Jang, Jessica L. Moore, and Dan Morrison. 2010. "The Effects of Altercasting and Counterattitudinal Behavior on Compliance: A Lost Letter Technique Investigation.” Communication Reports 23, no. 1: 1-13. doi: 10.1080/08934211003598759. 
Tutu, Desmond. 1997. “Address on Behalf of African Campaigns to Ban Landmines.” In Penny McMillin, Jean Lausberg, and Jakkie Cilliers, eds., Towards a Landmine-Free Africa: Proceedings of the First Continental Conference of African Experts on Landmines, 19-21 May. Pretoria, South Africa: Institute for Security Studies. At https://web.archive.org/web/20060225112416/http://www.issafrica.org/pubs/other/lan dminefree/CONTENT.HTML, accessed May 15, 2015.

Tutu, Desmond. 2007. “Statement to the Lima Conference on Cluster Munitions.” May. At http://www.wilpfinternational.org/disarmament/clustermunitions/LIMA/statements/T utu.pdf, accessed April 23, 2018.

UK Government. 2007. “Reports from the Defence, Foreign Affairs, International Development and Trade and Industry Committees.” Presented to Parliament, Session 2006-07. November. At https://www.gov.uk/government/uploads/system/uploads/attachment_data/file/24314 9/7260.pdf, accessed May 20, 2017.

Vines, Alex. 1995. “Timeless Bombs: The Southern Africa Minefield.” Southern Africa Report 11, no. 1. At http://kora.matrix.msu.edu/files/50/304/32-130-221E-84SAR\%2011-1\%20opt.pdf, accessed June 2, 2018.

Vreeland, James Raymond. 2008. "Political Institutions and Human Rights: Why Dictatorships Enter into the United Nations Convention against Torture.” International Organization 62, no. 1: 65-101. doi: 10.1017/S002081830808003X. Warmington, Valerie, and Celina Tuttle. 1998. “The Canadian Campaign.” In Maxwell A. Cameron, Robert J. Lawson, and Brian W. Tomlin, eds., To Walk Without Fear: The Global Movement to Ban Landmines. Toronto, Canada: Oxford University Press. Weinstein, Eugene A., and Paul Deutschberger. 1963. "Some Dimensions of Altercasting.” Sociometry 26, no. 4: 454-66, doi: 10.2307/2786148.

Weinstein, Eugene A., and Paul Deutschberger. 1964. “Tasks, Bargains, and Identities in Social Interaction.” Social Forces 42, no. 4: 451-56, doi: 10.2307/2574989.

Wellerstein, Alex. 2015. “Critical Mass.” In Restricted Data: The Nuclear Secrecy Blog. April 10. At http://blog.nuclearsecrecy.com/2015/04/10/critical-mass/, accessed May 24, 2018.

Wendt, Alexander. 1999. Social Theory of International Politics. New York, N.Y.: Cambridge University Press. 
Williams, Jody. 2008. “US Subverts the Cluster Bomb Ban.” Boston Globe. May 24. At http://www.boston.com/bostonglobe/editorial_opinion/oped/articles/2008/05/24/us_s ubverts_the_cluster_bomb_ban/, accessed April 7, 2017.

Williams, Jody. 2013. My Name is Jody Williams: A Vermont Girl's Winding Path to the Nobel Peace Prize. Oakland, Calif.: University of California Press.

Winograd Report. 2008. “Appendix: The Use of Cluster Bombs in the Second Lebanon War.” At http://www.adh-geneva.ch/RULAC/pdf_state/Winograd-report-chap-14-1.pdf, accessed May 2, 2010.

Wohlforth, William C., Benjamin de Carvalho, Halvard Leira, and Iver B. Neumann. 2018. "Moral Authority and Status in International Relations: Good States and the Social Dimension of Status Seeking.” Review of International Studies 44, no. 3: 526-46. doi: 10.1017/S0260210517000560.

\section{AUTHOR}

MARgARItA H. Petrova is a senior research fellow and academic coordinator of the master program in international security at the Institut Barcelona d'Estudis Internacionals (IBEI). Her research focuses on international norm development, NGO advocacy, ethical and legal issues in international security, and processes of securitization and desecuritization. She can be reached at mpetrova@ibei.org.

\section{ACKNOWLEDGMENTS}

For their valuable feedback, I thank Matthew Evangelista, Peter Katzenstein, Keith Krause, Stephanie Hofmann, Pascal Vennesson, and the editors and anonymous reviewers of World Politics. This article has also benefitted from comments at seminars at the Institut Barcelona d'Estudis Internacionals and the Centre on Conflict, Development, and Peacebuilding, Graduate Institute of International and Development Studies, Geneva, as well as from presentations at annual meetings of the American Political Science Association, the International Studies Association, and the European International Studies Association. 
I gratefully acknowledge the support from a research fellowship by the German Marshall Fund of the United States and a Marie Curie Intra-European Fellowship (MEIF-CT-2006039741).

\section{KEY WORDS}

Cluster munitions, developing states, humanitarian norms, land mines, naming and praising, NGO, norm cascades, weapon prohibitions

${ }^{1}$ Landmine Monitor 2006, 9.

${ }^{2}$ Just a few years before their prohibition, cluster munitions were used in the Iraq War. The UK insisted that a prohibition would open "serious capability gaps" in their armed forces; UK Government 2007. For the US, cluster munitions had “clear military utility”; Gates 2008.

${ }^{3}$ Finnemore and Sikkink 1998.

${ }^{4}$ Finnemore and Sikkink 1998.

${ }^{5}$ Brem and Stiles 2009.

${ }^{6}$ Cooper, English, and Thakur 2002; Rutherford, Brem, and Matthew 2003; Brem and Stiles 2009.

${ }^{7}$ Katzenstein 1996, 5.

${ }^{8}$ Finnemore and Sikkink 1998, 895.

${ }^{9}$ Checkel 2001; Acharya 2004; Gurowitz 2006; Cortell and Davis 2000.

${ }^{10}$ Keck and Sikkink 1998; Risse, Ropp, and Sikkink 1999; Risse, Ropp, and Sikkink 2013. Sikkink 2004 develops a revised insider-outsider coalition model.

${ }^{11}$ Finnemore and Sikkink 1998, 902.

${ }^{12}$ Lutz and Sikkink 2001, 4; Finnemore and Sikkink 1998, 902.

${ }^{13}$ Finnemore and Sikkink 1998, 901; Kelley 2008, 227.

${ }^{14}$ Finnemore and Sikkink 1998, 902.

${ }^{15}$ Price 2004, 110; Price 1998, 635.

${ }^{16}$ Phillips 2007, 716. Sikkink 2011 defines a cascade as a "shift in the legitimacy of the norm" when "norms spread rapidly," "in a relatively short time” (pp. 5, 11, emphasis in original). The original norm cascade definition centers on "rapid shifts in norms." Sunstein 1996, 909, 912. According to Schelling 1971, there is a "surge” at the tipping point (182-83).

${ }^{17}$ Finnemore and Sikkink 1998, 898, 902; Price 1998, 631, 635; Sikkink 2011, 22.

${ }^{18}$ Finnemore and Sikkink 1998, 902. 
${ }^{19}$ But see on arrested norm development, Krook and True 2012; Bailey 2008.

${ }^{20}$ Schelling's models involve "some activity that is self-sustaining once the measure of that activity passes a certain minimum level;” Schelling 1978, 94, 95; also, Kuran and Sunstein 1999, 683, and Granovetter 1978, 1422.

${ }^{21}$ No standard critical mass of fissile material triggers a chain reaction. It depends on density, shape, and temperature; Wellerstein 2015.

${ }^{22}$ Lutz and Sikkink 2000, 655.

${ }^{23}$ Finnemore and Sikkink 1998, fn 57. Treaty entry into force may not indicate a critical mass-e.g., the 1949 Geneva Conventions (and the 1977 Additional Protocols) entered into force after only two ratifications.

${ }^{24}$ A norm can cascade before legal institutionalization; Finnemore and Sikkink 1998, 900.

${ }^{25}$ As shown in Figures 1 and 2, a similar dynamic unfolds at the ratification phase when norms cascade even earlier, although the underlying mechanisms are a bit varied given the norms' institutionalized status.

${ }^{26}$ Finnemore and Sikkink 1998, 898.

${ }^{27}$ Price 2004, 110; Finnemore and Sikkink 1998, 902.

${ }^{28}$ Finnemore and Sikkink 1998.

${ }^{29}$ Petrova 2014.

${ }^{30}$ Here I build on Petrova 2016, 390, to elaborate on altercasting and its facilitating factors.

${ }^{31}$ Goffman 1959.

${ }^{32}$ Weinstein and Deutschberger 1963, 454.

${ }^{33}$ Weinstein and Deutschberger 1964, 455. Wendt uses the concept to depict social learning and identity (re)construction; Wendt 1999, 326-36.

${ }^{34}$ Turner et al. 2010, 3.

35 Turner et al. 2010, 3.

${ }^{36}$ Schimmelfennig 2003, 197; Finnemore and Sikkink 1998, 903-904.

${ }^{37}$ Busby 2010, 6, 39. Finnemore and Sikkink 1998, 902, mentions praise, albeit for conformity to group norms.

${ }^{38}$ See Pratkanis 2000.

${ }^{39}$ Gurowitz 2006.

${ }^{40}$ Paul, Larson, and Wohlforth 2014; Pouliot 2016.

${ }^{41}$ Neumann and de Carvalho 2015; Erickson 2015; Wohlforth et al. 2018.

${ }^{42}$ Neumann 2014. 
${ }^{43}$ Schimmelfennig 2003.

${ }^{44}$ Neumann and de Carvalho 2015, 2; Wohlforth et al. 2018, 532; Larson, Paul, and Wohlforth 2014, 17.

${ }^{45}$ Pratkanis 2000, 210.

${ }^{46}$ Pratkanis and Gliner 2004, 283.

${ }^{47}$ On the importance of intrinsic motivation for self-esteem, see Gecas 1982, 17-18.

${ }^{48}$ Pratkanis 2007, 34-35.

${ }^{49}$ Markwica 2018.

${ }^{50}$ Turner et al. 2010, 3.

${ }^{51}$ Gecas 1982, 6; Pratkanis 2000, 219.

52 On stigma management, see Adler-Nissen 2014.

${ }^{53}$ See Petrova 2016 for the UK case.

${ }^{54}$ But see recent work on the contributions of developing states to human rights norms, Jensen 2016; Sikkink 2017, 55-93.

55 The juxtaposition with big powers also puts NGOs and small states in a unified category of weak but righteous actors.

${ }^{56}$ Schimmelfennig 2003.

${ }^{57}$ Finnemore 2009; Farrell and Finnemore 2013. On organized hypocrisy in international institutions and, broadly, world politics, see Krasner 1999; Lipson 2007.

${ }^{58}$ This later phase of norm development remains beyond the scope of this article. The effects of positive altercasting on ratification speed depend on a range of factors, including the persistence and strength of NGO campaigning, which has to shift to the domestic level, exert pressure on parliamentarians, and deal with different legal systems and requirements for ratifications. They also depend on the fact that leadership dividends already reaped can weaken the incentive to keep playing a vanguard role because of the low marginal utility of additional status gains or diminished issue salience.

${ }^{59}$ Price 1998, 617. Both prohibitions are based on IHL principles of distinction and proportionality and the CM ban built upon the prior mine ban.

${ }^{60}$ Finnemore and Sikkink 1998; Crawford 2002; Sandholtz and Stiles 2008.

${ }^{61}$ Finnemore and Sikkink 1998, 909; Risse, Ropp, and Sikkink 1999, 21.

${ }^{62}$ Convention on Prohibitions or Restrictions on the Use of Certain Conventional Weapons Which May be Deemed to be Excessively Injurious or to Have Indiscriminate Effects (CCW). 
${ }^{63}$ African, Latin American, and Pacific Island states accounted for 51 and 54 percent of ratifications in the first two and a half years of the CCM and MBT, respectively, versus 18 and 17 percent for Protocol V and Amended Protocol II.

${ }^{64}$ The land mine treaties were adopted in two consecutive years. The ERW Protocol and CCM were slightly less than five years apart.

${ }^{65}$ Cassese 1986, 269.

${ }^{66}$ Vreeland 2008; Greenhill and Strausz 2014.

${ }^{67}$ Cole 2005; Hathaway 2007; Hafner-Burton 2012. Beyond ratification, Comstock 2019 examines the relationship between postcommitment actions and human rights practices.

${ }^{68}$ Fifteen in-person and three semi-structured telephone interviews of about sixty minutes on average. To maintain confidentiality, I have not identified the names of the government or NGO officials interviewed. No location is given for telephone interviews or for the cases where specifying the location or the person's country might reveal the subject's identity.

${ }^{69}$ Rutherford 2010, 19-27.

${ }^{70}$ Goose 2004, 247. The CCM definition is more technical.

${ }^{71}$ See Borrie 2009 for background on the cluster munition case.

${ }^{72}$ Lutz and Sikkink 2000, 655.

${ }^{73}$ The supplementary material provides detailed measures of early state support; Petrova 2019.

${ }^{74}$ International Campaign to Ban Landmines 1997b, 43.

${ }^{75}$ Author interview with government official, Geneva, Switzerland, May 25, 2009; Human Rights Watch et al. 2009, 177.

${ }^{76}$ Author telephone interview with government official, June 20, 2016.

${ }^{77}$ Price 2004, 121.

${ }^{78}$ Price 1998, 641.

${ }^{79}$ International Campaign to Ban Landmines 1996, 96; Smith 2008, 74.

${ }^{80}$ According to an African NGO representative, the side effect of activism in the Oslo Process would be attracting funding for other issues; author interview with NGO official, Dublin, Ireland, May 17, 2008.

${ }^{81}$ Landmine Monitor 1999, 25, 27.

${ }^{82}$ A chi-square test for the connection between the mine contamination of all sub-Saharan African countries and early ratification isn't statistically significant. Nor is it statistically significant for the combined groups of African and Latin American, or African, Latin American, and Pacific Island states.

${ }^{83}$ Landmine and Cluster Munition Monitor 2016. 
${ }^{84}$ Norway, Austria, New Zealand, Mexico, Ireland, and initially Peru.

${ }^{85}$ Author interview with government official, Geneva, Switzerland, November 15, 2012.

${ }^{86}$ Of twenty-seven new countries, twenty-two were developing nations (and twelve of those were African); Katherine Harrison, "Report from the Lima Conference on Cluster Munitions 23-25 May 2007.” At

http://web.archive.org/web/20080523180206/http://www.wilpf.int.ch/disarmament/clustermunitio ns/LIMA/limareport.html, accessed May 5, 2015.

${ }^{87}$ Tutu 2007.

${ }^{88}$ Author interview with NGO official, Dublin, Ireland, May 17, 2008.

${ }^{89}$ Quoted in Dube 2009, 9.

${ }^{90}$ E.g., Mtonga 2007; Norwegian diplomat quoted in Dube 2009, 7.

${ }^{91}$ Livingstone Declaration on Cluster Munitions. At https://oldsite.issafrica.org/uploads/LIVINGSTONEDECL.PDF, accessed May 5, 2015.

${ }^{92}$ Author interview with government official, Dublin, Ireland, May 27, 2008; author interview with government official, Geneva, Switzerland, May 27, 2009.

${ }^{93}$ Author interview with NGO official, Dublin, Ireland, May 17, 2008.

${ }^{94}$ Cluster Munition Coalition 2008c.

${ }^{95}$ Cluster Munition Coalition 2008c.

${ }^{96}$ CMC Coordinator Thomas Nash, quoted in "Zimbabwe: Need for Cluster Bomb Ban Treaty.” March 31, 2008. At http://www.landmine.de/archiv/oeffentlichkeitsarbeit/news/newsdetailseite/article/zimbabwe-need-for-cluster-bomb-ban-treaty-zimbab.html, accessed May 5, 2018.

${ }^{97}$ Borrie 2009, 275, 257-58.

98 "Western Nations Complain that NGOs Forced through Cluster Bomb Ban.” June 6, 2008. At http://www.landmine.de/archiv/oeffentlichkeitsarbeit/news/news-detailseite/article/westernnations-complain-that-ngos-forced-through.html, accessed July 7, 2018; author interview with government official, Geneva, Switzerland, May 25, 2009.

${ }^{99}$ Author notes, Dublin Diplomatic Conference on Cluster Munitions, May 23, 2008.

${ }^{100}$ Mweemba 2008, 9.

${ }^{101}$ Pande quoted in Daily Parliamentary Debates for the Third Session of the Tenth Assembly, March 10, 2009, at http://www.parliament.gov.zm/node/1624, accessed June 23, 2018. Similarly, Foreign Minister Effron Lungu argued that by hosting the 2013 Meeting of States Parties, Zambia would benefit from a "boosted international image as a partner in global peace [and] promotion of the country's image at international for a;” quote from the Daily 
Parliamentary Debates for the Second Session of the Eleventh Assembly, July 11, 2013, at http://www.parliament.gov.zm/node/673, accessed June 23, 2018.

102 “Africa has been crucial to ensuring the creation of a strong treaty banning cluster munitions. Now African states should unite to ensure every government follows through and signs the Convention,” quote from Cluster Munition Coalition 2008e; “a major humanitarian success ... that African nations had a strong guiding hand in bringing about”, "it was not just that African states turned up to the meetings, it was not just the numbers, but at every step of the process .... African states worked to make this treaty stronger", "We are still relying on you ... to take this work forward and to make this treaty happen,” quotes from Cluster Munition Coalition 2008f. See also, Dube and Stott 2008.

${ }^{103}$ Author interview with government official, Geneva, Switzerland, November 15, 2012; author interview with NGO official, Geneva, Switzerland, November 13, 2012. Twenty-four of fifty states that issued a declaration against a weaker CCW protocol were African (fifteen were Latin American); Cluster Munition Monitor 2012, 12.

${ }^{104}$ Author telephone interview with government official, November 28, 2012.

${ }^{105}$ Author interview with NGO official, Ithaca, N.Y., March 2, 2005; Williams 2013, 211.

${ }^{106}$ International Campaign to Ban Landmines 1995a.

${ }^{107}$ Vines 1995.

${ }^{108}$ International Campaign to Ban Landmines 1994, Landmines Update no. 7, April.

${ }^{109}$ Mandela 1993, 87.

${ }^{110}$ Quote from Mail \& Guardian, September 29, 1995. At http://mg.co.za/article/1995-

09-29-outrage-as-sa-treads-carefully-on-landmines, accessed July 7, 2018.

${ }^{111}$ International Campaign to Ban Landmines 1995a.

${ }^{112}$ Mail \& Guardian, March 3, 1995. At http://mg.co.za/article/1995-03-03-call-forafrica-to-ban-its-hidden-killers, accessed July 7, 2018.

${ }^{113}$ Mail \& Guardian, September 29, 1995. At http://mg.co.za/article/1995-09-29-outrageas-sa-treads-carefully-on-landmines, accessed July 7, 2018.

${ }^{114}$ Quoted in International Campaign to Ban Landmines 1995b, 68.

${ }^{115}$ International Campaign to Ban Landmines 1995b, 53.

${ }^{116}$ Stott 1998, 72, emphasis in original.

${ }^{117}$ Cilliers 1997.

${ }^{118}$ Quoted in Mail \& Guardian, October 11, 1996. At http://mg.co.za/article/1996-10-11sa-joins-call-for-ban-on-mines, accessed July 7, 2018.

119 “Open Letter to President Mandela,” October 14, 1996. At https://www.africa.upenn.edu/Urgent_Action/apic_111596.html, accessed July 7, 2018. 
${ }^{120}$ South African Campaign to Ban Landmines, "Military Veterans Urge Mandela to Ban Landmines.” Press release, October 15, 1996. At https://www.africa.upenn.edu/Urgent_Action/apic_111596.html, accessed July 7, 2018.

${ }^{121}$ Mail \& Guardian, May 23, 1997. At http://mg.co.za/article/1997-05-23-double-profiton-landmines, accessed July 7, 2018.

${ }^{122}$ South African Campaign to Ban Landmines, “Campaigners Welcome South Africa’s Announcement of a Landmines Ban as a ‘Triumph'.” Press release, February 20, 1997. At http://web.archive.org/web/19980110171218/http://www.pgs.ca/pages/lm/ld970222.htm, accessed July 7, 2018.

${ }^{123}$ Quoted in International Campaign to Ban Landmines 1997a, 4.

${ }^{124}$ Vietnam Veterans of America Foundation, "Mozambique Announces Landmine Ban at Conference.” Press release, February 26, 1997. At http://web.archive.org/web/19980614043245/http://www.vvaf.org/landmine/international/updates /events/latemaputo.html, accessed July 7, 2018.

${ }^{125}$ McMillin, Lausberg, and Cilliers 1997, Appendix K "Final Declaration of the 4th International NGO Conference on Landmines, Maputo, Mozambique.” At http://web.archive.org/web/20060225112416/http://www.issafrica.org:80/PUBS/OTHER/Landmi neFree/CONTENT.HTML, accessed July 7, 2018.

${ }^{126}$ South African Campaign to Ban Landmines, “African Campaigns Urge Governments to Ban Landmines, Clear them, Help Survivors, Sign Ban Treaty.” Press release, May 16, 1997. At http://www.africa.upenn.edu/Urgent_Action/apic_52097.html, accessed July 7, 2018.

${ }^{127}$ Human Rights Watch 1997.

${ }^{128}$ At the OAU regional meeting on land mines, South Africa’s vice president, Thabo Mbeki, argued, "Africa can become the first continent to take a collective decision against this evil device.... Outside of our continent, the perception persists that Africa remains, as of old, torn by interminable conflict, unable to solve its problems, condemned to the netherworld... There exists within our continent a generation which has been victim to all the things which created this negative past. This generation remains African and carries with it an historic pride which compels it to seek a place for Africans equal to all the other peoples of our common universe. It is this generation whose sense of outrage against the exploitation of the past, as well as continued exploitation, guarantees Africa’s advance towards its rebirth”; Mbeki 1997. Similarly, Tutu talked about Africa's “giant re-awakening” despite outside views that the continent was "best forgotten, shoved off the agendas of the world”; Tutu 1997.

\footnotetext{
129 Tutu 1997.

${ }^{130}$ Stott 1998, 73, 74.
} 
${ }^{131}$ Landmine and Cluster Munition Monitor 1999.

132 Tutu 1997.

${ }^{133}$ Nel, Taylor, and van der Westhuizen 2000, 56.

${ }^{134}$ Author interview with NGO official, Geneva, Switzerland, May 14, 2006; author interview with NGO official, Geneva, Switzerland, November 30, 2012; Maslen 2004, fn 212; Williams 2013, 215, 224.

${ }^{135}$ Landmine and Cluster Munition Monitor 1999. Canada was the only other country to destroy its stockpiles before signing the treaty.

${ }^{136}$ Mozambican Campaign Against Landmines 1997b.

${ }^{137}$ Nel, Taylor, and van der Westhuizen 2000, 54. The Norwegian deputy foreign minister at the time, Jan Egeland, alluded to the same leadership ranking during the process when he said that Norway "moved up front at the end and finish[ed] as a good number two right after Canada. South Africa moved with us, really”; quoted in Neumann 2002, fn 25.

${ }^{138}$ Mozambican Campaign Against Landmines 1997b.

${ }^{139}$ Mozambican Campaign Against Landmines 1997a.

${ }^{140}$ Neier 2012, 211, 208.

${ }^{141}$ Author interview with NGO official, July 28, 2004.

${ }^{142}$ Maslen 2004, 43, fn 214.

${ }^{143}$ Sigal 2006, 181, 190.

${ }^{144}$ NGO representative quoted in Sigal 2006, 202, 201.

${ }^{145}$ Sigal 2006, 201.

146 The Ottawa Process was permeated by a "common desire to stand up against U.S. power in the world,” Cottrell 2009, 241; Cottrell 2016, 130.

${ }^{147}$ Quoted in Sigal 2006, 202.

${ }^{148}$ Author telephone interview with government official, May 11, 2016.

${ }^{149}$ Author telephone interview with government official, May 11, 2016.

${ }^{150}$ Author telephone interview with government official, May 11, 2016.

${ }^{151}$ Williams 2013, 200.

${ }^{152}$ According to a Canadian arms control expert, the Ottawa Process was "as much about ... a moral cause and exercising leadership as a middle power that the United States could not”; quoted in Cottrell 2016, 131.

153 “Clinton in a Bind over Land Mines: U.S. Gets Left behind as Canada Pushes International Ban,” Ottawa Citizen, August 10, 1997.

154 “U.S. Joins Canada in Drive to Ban Landmines,” Ottawa Citizen, August 19, 1997.

${ }^{155}$ Cluster Munition Coalition 2008b; Williams 2008. 
${ }^{156}$ Warmington and Tuttle 1998, 57.

${ }^{157}$ Author interview with NGO official, Geneva, Switzerland, May 14, 2006.

${ }^{158}$ NGO member quoted in Neumann 2002, 124; author interview with NGO official, Geneva, Switzerland, May 14, 2006.

${ }^{159}$ Author interview with government official, April 29, 2009.

${ }^{160}$ Mozambican Campaign Against Landmines 1997a.

${ }^{161}$ Three issues informed military opposition and largely shaped the US position: banning US antitank mines in mixed systems with antipersonnel land mines, mine use in Korea, and establishing a slippery slope for banning other weapons. In the negotiations, the US dropped most of its demands. Ultimately, it unsuccessfully tried to get two provisions to allow some exceptions for Korea-a clause "providing individual states an option of deferring compliance with certain treaty provisions for nine years from signature” and a modification of the clause not allowing withdrawal from the treaty in times of armed conflict— to make clear that "this restriction would not apply if the withdrawing party or its ally is a victim of armed aggression in violation of the UN charter”; International Campaign to Ban Landmines 1997b, 36, US proposal. Given that in 2014, President Barak Obama declared that the US banned the use of all antipersonnel land mines except on the Korean Peninsula, the need for land mines in Korea appears to have been the primary reason for military opposition. Although emplaced mines in Korea are under the responsibility of South Korea, remaining issues include mine use in conflict by US forces or by South Korean forces under US command; Landmine and Cluster Munition Monitor 2017c

162 Clinton 2004, 765.

163 Sigal 2006, 205.

${ }^{164}$ Borrie 2009, 319.

165 Author interview with government official, April 27, 2009.

${ }^{166}$ Author interview with government official, April 27, 2009. According to core-group diplomats, a UK statement in Wellington “that most countries in the hall didn’t have any idea about the issues and should not even be there, in view of its colonial history, played the role of a wakeup call for the African states that formed the group of affected and friends of affected countries. The result was radicalization of the issue"; author interview with government official, April 27, 2009; also telephone interview with government official, November 28, 2012. This attitude toward the participation of developing states also transpired in interviews with British diplomats- “they are here to make the numbers. They don't have any problems and were brought here in an appalling way," or, more bluntly, "they were paid to be there”; author interview with government official, Vienna, Austria, December 6, 2007; author interview with government official, Geneva, Switzerland, May 25, 2009. 
${ }^{167}$ Borrie 2009, 215.

168 “Day Three-Wellington Conference,” Aotearoa New Zealand Cluster Muntion Coalition. February 20, 2008. At

http://web.archive.org/web/20081014151034/http://www.stopclusterbombs.org.nz/2008/02/20/19 3/, accessed July 7, 2018.

${ }^{169}$ Cluster Munition Coalition 2008a.

${ }^{170}$ Cluster Munition Coalition 2008b; Associated Press, "Nobel Peace Laureate Says US Trying to Stall Cluster Bomb Agreement,” February 21, 2008. At https://www.commondreams.org/news/2008/02/21/nobel-peace-laureate-says-us-trying-stallcluster-bomb-agreement.

${ }^{171}$ United Kingdom Ambassador John Duncan, "Statement on Article I: General Scope and Obligations.” Wellington Conference on Cluster Munitions, February 18, 2008. At http://web.archive.org/web/20100522165157/http://www.mfat.govt.nz/clustermunitionswellingto n/conference-documents/UK-intervention.pdf, accessed July 7, 2018.

${ }^{172}$ Author interview with government official, Geneva, Switzerland, May 27, 2009.

173 The Times, “Gordon Brown’s Call for Ban on Cluster Bombs Puts Pressure on MoD,” May 22, 2008.

${ }^{174}$ US State Department, “Ambassador Mull Briefs on U.S. Cluster Munitions Policy,” May 21, 2008. At http://web.archive.org/web/20080601032416/http://www.america.gov/st/texttransenglish/2008/May/20080522163101eaifas0.8921015.html, accessed July 7, 2018.

${ }^{175}$ Handicap International France, “L’Inadmissible Chantage des Etats-Unis,” May 28, 2008. At http://web.archive.org/web/20081208111443/http://www.sousmunitions.fr/actualites/, accessed July 7, 2018.

${ }^{176}$ Cluster Munition Coalition 2008d; Williams 2008; Reuters, “US ‘Bullying’ Hurts Cluster Bomb Ban Work-Activists,” May 23, 2008. At http://uk.reuters.com/article/2008/05/23/idUKL2351197020080523, accessed July 7, 2018.

${ }^{177}$ Author notes, panel on the US position on cluster munitions, Dublin Diplomatic Conference on Cluster Munitions, May 26, 2008; Irish Star, “'Lame Duck’ Bush Avoids Cluster Bomb Conference,” May 27, 2008.

${ }^{178}$ Handicap International UK, “Affected and Developing Countries Lead the Way to a Ban on Cluster Munitions,” February 22, 2008. At http://www.landmine.de/archiv/oeffentlichkeitsarbeit/news/news-detailseite/article/affected-anddeveloping-countries-lead-the-way-to.html, accessed May 2, 2016.

${ }^{179}$ Price 2004; Bower 2015. 
${ }^{180}$ The section on the US case draws on Petrova 2018, 645-49.

${ }^{181}$ Opening Statement by Stephen Mathias, Head of US Delegation to the CCW-Group of Governmental Experts Meetings, July 7, 2008. At

https://geneva.usmission.gov/2008/07/07/gge-opening-jul07-2008/, accessed 18 March 2018.

${ }^{182}$ Gates 2008.

${ }^{183}$ Landmine and Cluster Munition Monitor 2017a.

${ }^{184}$ Human Rights Watch 2009, 255.

${ }^{185}$ Hudson 2016.

${ }^{186}$ Quoted in Schatz 2016.

${ }^{187}$ Cluster Munition Monitor 2017, 20.

${ }^{188}$ Amnesty International 2010; Cluster Munition Coalition 2010.

${ }^{189}$ Risse, Ropp, and Sikkink 1999.

${ }^{190}$ Landmine and Cluster Munition Monitor 2017a.

${ }^{191}$ Quoted in Landmine and Cluster Munition Monitor 2017b.

192 Quoted in Landmine and Cluster Munition Monitor 2015a.

${ }^{193}$ Winograd Report 2008, emphasis in original.

${ }^{194}$ Quoted in Landmine and Cluster Munition Monitor 2015a.

${ }^{195}$ Landmine and Cluster Munition Monitor 2017b.

${ }^{196}$ Quoted in Human Rights Watch et al. 2009, 232.

${ }^{197}$ Quoted in Landmine and Cluster Munition Monitor 2015b.

${ }^{198}$ Human Rights Watch 2015; Amnesty International 2015.

${ }^{199}$ Russian Ministry of Defence 2015.

${ }^{200}$ Human Rights Watch 2016.

${ }^{201}$ Quoted in Cluster Munition Monitor 2017, 16.

${ }^{202}$ Human Rights Watch 2017, 2018.

${ }^{203}$ E.g., the recent campaign to ban nuclear weapons.

${ }^{204}$ Ikenberry 2001; Finnemore 2009; Farrell and Finnemore 2013. 